\title{
'Good fences make good neighbours': Concepts and records of range dynamics in ground squirrels and geographical barriers in the Pleistocene of the Circum-Black Sea area
}

\author{
L.V. Popova, L.C. Maul, V. Zagorodniuk, Yu.M. Veklych, P.S. Shydlovskiy, N.V. Pogodina, K.M. \\ Bondar, T.V. Strukova, S.A. Parfitt \\ Quaternary International 509 (2019) 103-120
}

\begin{abstract}
Ground squirrels were an important member of the Pleistocene steppe-tundra mammal community. They evolved ecological specialisations and exhibit behaviours that make them particularly informative subjects to study palaeoenvironmental constraints affecting species distribution and speciation. Interspecific competition and isolating geographical barriers are considered as the principal factors that define species range boundaries.
\end{abstract}

The present paper provides a first comprehensive compilation of the living and extinct Spermophilus species in Europe. These data suggest 'patchwork quilt' model for the expansion and spatial distribution of ground squirrel species. Here we consider mainly small-sized Spermophilus species because large-sized (e.g., S. superciliosus) ground squirrels consist another 'patchwork quilt', which overlap the first one. This overlapping of the species ranges is possible because of the size difference that lowers interspecific competition (Hutchinson's rule).

We consider two main types of range boundaries. One type includes roughly 'sub-parallel' boundaries that oscillate in concert with climatic and vegetational changes (a case of climatically controlled competitive exclusion). The other type consists of roughly 'sub-meridional' boundaries corresponding to geographical barriers (e.g., water barriers, mountain ridges); these boundaries are rather stable. Examples of 'sub-parallel range modifications include: oscillations of boundaries between S. pygmaeus and S. suslicus; the immigration of S. citellus into the Pre-Carpathian area; the branching of S. suslicus from S. pygmaeus; the regional appearance of the Late Pleistocene species $S$. severskensis and S. citelloides. Examples of 'sub-meridional events' are: the crossing of the Danube by S. citellus; the appearance of an isolated population of S. pygmaeus on right bank of the Dnieper during the Late Pleistocene to Middle Holocene; a crossing of the Dnieper river by S. pygmaeus, which resulted in the appearance of $S$. odessanus; the intrusion of eastern populations of $S$.

pygmaeus into the Trans-Volga areas.

Keywords: Spermophilus, Quaternary, Palaeobiogeography, Species range dynamics, Interspecific competition, Geographical barriers

\section{Introduction}

Range dynamics and biogeography of plant and animal species during the Quaternary provide an extremely fertile topic for multidisciplinary research. Understanding shifting distribution patterns is linked intimately to changes in palaeogeography and climate, which interact with edaphic factors (e.g. nutrient availability) and interspecific competition. These are some of the main 'drivers' for evolution in Quaternary mammals, with isolated populations often providing the 'laboratory' for 
speciation events and microevolution. Several multidisciplinary research groups have been working on such issues, with special focus on human dispersal (e.g., Gamble, 2003; Yanko-Hombach et al., 2010; Stewart and Stringer, 2012; Péan and Prat, 2014; Péan et al., 2015; Rodríguez et al., 2016; and others). These studies have produced data on climatic factors and sea-level change, which are important for 'opening' and 'closing' pathways for biotic expansion into previously unoccupied regions.

A challenge for biogeographers is to elucidate how the evolution of inland barriers is linked to Pleistocene biotic changes. This requires selecting suitable groups of plants and animals which are known to be sensitive to changes in the configuration of these barriers. Ground squirrels of the genus Spermophilus are one such potentially informative group. It is expected that the reconstruction of the dynamics of their Pleistocene ranges enables to recognise palaeogeographical events, which served as physical constraints for biotic distribution. Together with previously obtained palaeogeographical information, insights in range dynamics of ground squirrels will be a useful complementary contribution to reconstruct large-scale river channel changes, fluvial network transformation and sea level changes during the Quaternary.

The present paper reviews: (1) the ecological background of range dynamics in ground squirrels; (2) palaeontological, phylogeographical and other information relating to selected ground squirrel species during phases of range expansion and contraction; and (3) the causal factors in the Quaternary environment that might have controlled these dispersal events.

Ground squirrel species considered in this article, are the extant Spermophilus citellus (Linnaeus, 1766), S. suslicus (Güldenstädt, 1770), S. pygmaeus (Pallas, 1778), S. major (Pallas, 1779), S. fulvus (Lichtenstein, 1823), S. musicus Ménétries, 1832, S. xanthoprymnus Bennett, 1835, S. suslicus Guldenstaedt, 1770 and S. odessanus Nordmann, 1842 (S. suslicus sensu lato means S. suslicus sensu stricto + S. odessanus - see section 4.5), and the extinct ground squirrels S. superciliosus Kaup, 1839, S. citelloides Kormos, 1916, S. primigenius (Kormos, 1934), S. musicoides (Gromov, 1957), S. nogaici (Topachevskij, 1957), S. polonicus (Gromov et al., 1965), and S. severskensis (Gromov et al., 1965).

\section{Ecological background of range dynamics of ground squirrels}

Ground squirrels display peculiarities in ecology and behaviour, which make them very suitable subjects to study palaeoenvironmental constraints affecting species distribution and speciation. The main peculiarities are: a burrowing lifestyle, hibernation, coloniality, and particular complex social behaviour. In combination, these factors limit the ability of ground squirrels to undertake long journeys or cross physical barriers (Bielskiy, 1929; Ćosić et al., 2013). As a result, a relatively strict allopatry is observed, and range boundaries generally coincide with significant geographical barriers, e.g., rivers (Zagorodnyuk, 2002) (Fig. 1a). When both sides of larger rivers are inhabited by the same species (e.g., Spermophilus pygmaeus in the Volga area), molecular-genetic studies usually show a high isolation effect due to the physical barrier created by the river (Ermakov et al., 2006b); however, there are exceptions to this pattern (Kuzmin et al., 2011; Ćosić et al., 2013) (Fig. 1d), which will be discussed below. 


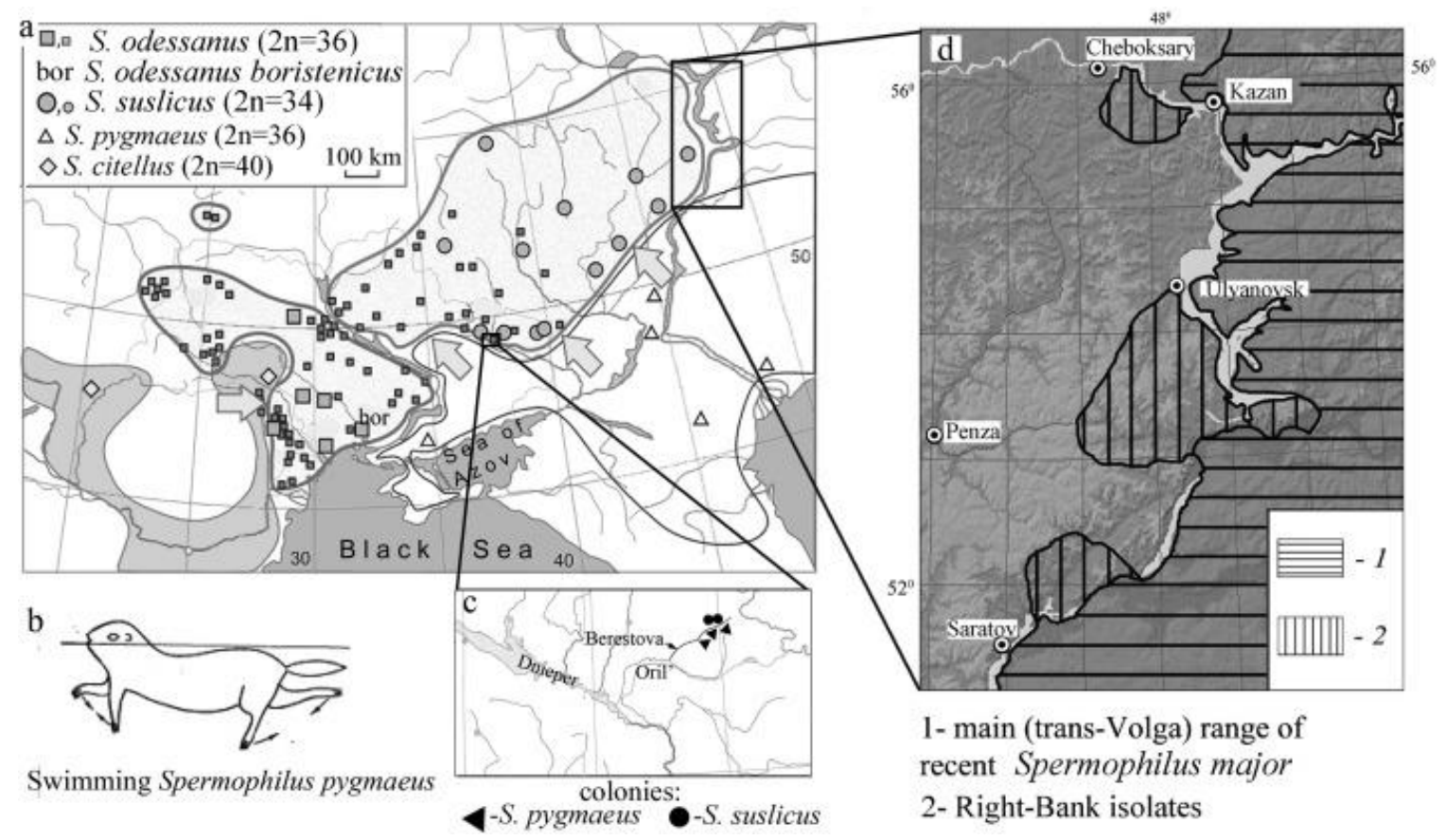

Fig. 1. (a) Correspondence between geographical barriers (larger rivers, Carpathian mountains) and ranges of extant smaller-sized ground squirrels in the East European Plain (from Zagorodnyuk, 2011). (b) Swimming ground squirrel (from Kalabukhov, 1978, p. 44). (c) Even small rivers can be barriers isolating populations, in this example separating S. pygmaeus and S. suslicus on either side of the Berestova River (based on data of Sivkov, 1962). (d) Large water bodies are not always insurmountable barriers: right-bank isolates of Spermophilus major in the Volga area (from Kuzmin et al., 2011).

The influence of topography on ground squirrel behaviour varies according to species, and is particularly marked in mountainous areas, where mountain ridges may act as formidable barriers to ground squirrel dispersal. Other barriers are larger water-bodies. Recent ground squirrels avoid settling within floodplains; As noted by Gromov et al. (1965, p. 216) about S. suslicus: 'they, as well as other ground squirrel species, avoid wet soils and rare settle in low places, preferring elevations'. This inability to cope with waterlogged ground is an important contributory factor that further reduces their ability to cross rivers. In addition, ground squirrels hibernate during the winter, and this means that they are unable to take advantage of frozen rivers to reach new habitats. It is not only large rivers that act as barriers; smaller rivers can also block ground squirrel dispersal, for example the Siverskyi Donets, Psiol, and even the tiny Berestova river (Fig. 1C) form part of the boundary between the ranges of $S$. pygmaeus and S. odessanus.

Ground squirrels are able to swim to some extent (Kalabukhov and Raevskij, 1935; Ćosić et al., 2013) (Fig. 1b). The highest observed swimming-speed is $9.5 \mathrm{~m}$ per minute, and the maximal duration of floating is $15 \mathrm{~min}$ for the most mobile, small-sized ground squirrel, S. pygmaeus (Bielskiy, 1929). Thus, the animals would be able physiologically to cross small slow-flowing rivers. However, the barrier effect can be reinforced if colonies of another ground squirrel species are present on the opposite bank (Bielskiy, 1929; Sivkov, 1962). In these cases the river is merely a natural line of demarcation between colonies with interspecific mutual repulsion, because of different alarm calls (Sivkov, 1962). 
Interspecific interactions in the adaptive zone are important constraints responsible for maintaining range boundaries between ground squirrel species. These interactions include competition and interspecific hybridization or risks (of extinction) of the latter. Owing mostly to the burrowing lifestyle, interspecific interactions in ground squirrels are often confrontational. Although different species prefer somewhat different habitats (Titov et al., 2012), several important requirements coincide. Optimal habitats include elevated areas along south-facing slopes, with burrows protected by a 'waterproof' loam or silt capping of loose or loamy sand suitable for burrowing and construction of dwelling chambers (Popova, 2015). This forces interspecific competition, not only for food, but also for suitable settlement places. Therefore, competition between ground squirrel species is more intense than amongst most other small mammal species.

Nevertheless, competition is not always strong enough to separate different Spermophilus species. There are cases of mixed, two-species colonies, resulting in interspecific hybridization (Shmyrov, 2006; Zagorodnyuk, 2011; Titov et al., 2012). Ease of interspecific hybridization is considered to be evidence of evolutionary young sister-species (Vorontsov and Lyapunova, 1969; Zagorodnyuk, 2002, 2011; Ermakov et al., 2006a). An example is branching between S. major and S. fulvus, which is considered to have taken place during the Holocene (Gromov et al., 1965; Agadjanian, 2006; Popova, 2016a). However, in the cases of hybridization between S. suslicus and S. pygmaeus, or $S$. citellus and S. odessanus (Zagorodnyuk, 2011) the divergence times between the species are far more ancient (Gromov et al., 1965; Rekovets, 1994). For these species, hybridization must be explained by other reasons, such as the bottlenecks of the adaptive zone forcing ground squirrels to form mixed colonies. Such mixed colonies, however, may not be long-lasting: survival in a hybrid colonies is low, e.g., up to 14\%, in the case of S. major/S. fulvus (Shmyrov, 2006) and the zone of hybridization disappears after some time (Zagorodnyuk, 2011). Eventually, this enhances reproductive isolation (individuals, inclined to interspecific mating become 'out of the running' Mayr, 1963), and thereby, the zone of parapatry shrinks. Recent widespread sympatry, symbiotopy and occurrence of hybrid populations in ground squirrels are considered to be mainly due to anthropogenic factors. Agriculture and other human modification of the landscape have reduced the extent of biotopes suitable for ground squirrel settlements; on the other hand, arable land may provide them with unprecedented food abundance in areas where cereal crops are grown. The influence on ground squirrels of such man-made changes of ecosystems and fauna were first recorded in the 1930s (Bielskiy, 1929; Kalabukhov and Raevskij, 1935). Therefore, we conclude that ecological and geographical vicariance, rather than sympatry and hybridization, is the typical type of interspecific interaction under natural conditions in un-altered ecosystems.

Ecological and geographical vicariance can be caused by climatically controlled competitive exclusion (Park, 1954). A good example of such a replacement are the recent species S. pygmaeus and S. suslicus (Zagorodnyuk and Fedorchenko, 1995; Zagorodnyuk, 2002): the more xerophilous $S$. pygmaeus occupies the southern part of the Trans-Dnieper area, whereas the more mesophilous $S$. suslicus inhabits areas in the north. The boundary between their ranges has been modified in response to landscape and climatic changes. Currently, the range of S. pygmaeus is expanding to the north, whilst the range of $S$. suslicus is contracting due to agricultural transformation of landscape have led to increased aridity (Hare, 1983). Another example where modern climate changes have shifted range boundaries of ecological vicariants, has been observed in S. citellus and S. odessanus (Zagorodnyuk, 2011). 
Barrier effects of rivers would have varied with Pleistocene environmental fluctuations, with rivers shifting from single-thread, meandering courses to complex braided systems in different climatic regimes (Gibbard and Lewin, 2002). Such changes in the configuration of rivers have been proposed as an explanation for the spatial distribution of Epigravettian archaeological sites in the Dnieper area (Shydlovskyi, 2005a). Late Pleistocene mammoth hunters used camps of two types: base camps, such as Mezhyrich, near river floodplains, and summer camps on the plateau. Two seasonal types of hunting activity suggest that the main mammoth pastures within floodplains were unsuitable during the spring-summer period for mega-herbivorous (Shydlovskyi, 2005b), and even more so for ground squirrels. Therefore, during particular parts of the Pleistocene, not only large rivers, such as the Danube, Dniester, Dnieper and Don, caused interspecific isolation, but also smaller rivers, such as the Ros' (the 'hunting ground' of Epigravettian hunters at Mezhyrich).

Effects of valley slopes should be considered separately from isolation effect of rivers. These slopes are preferred places for ground squirrels to settle. They are especially important for species living under the severe conditions of modern tundra zone, such as Urocitellus undulatus (Pallas, 1778) and U. parryi (Richardson, 1825). South-facing slopes become clear of snow earlier in the spring, which allows an earlier seasonal start of foraging (Gromov et al., 1965). Spermophilus populations that settle along valleys, also benefit from food resources of floodplains. For example, the floodplain of the Irbit river, near the village Skorodumskoye $\left(\mathrm{N} 57^{\circ} 55^{\prime}, \mathrm{E} 62^{\circ} 75^{\prime}\right.$ ), provides foraging areas for a peripheral population of Spermophilus major that inhabits the pine and birch preforest-steppe zone of the West-Siberian Plain. Here, ground squirrels occur in meadows, fields, pasture along the river banks and near forest edges (Lemesh and Pogodina, 2010). Exceptionally, burrows occur in the high flood-plain of the Irbit river, where ground squirrel colonies may occasionally suffer from flooding (Lemesh and Pogodina, 2010). This occasional mortality is the cost of living in a valley refuge confined by unsuitable zonal biotopes.

Nowadays, river valleys share this refugial role with other ecotones created by human activity (e.g. roadside verges, pasture, forest edges and clearings). However, the carrying capacity of floodplains is higher, with the added advantages of the safety provided by the upper parts of slopes. In the past, without man-made alterations of open landscapes, the significance of river valleys as refugia would have been even higher.

Climate changes during the Quaternary are likely to have modified both the barrier effect of rivers and the refugial significance of valleys. For the vegetation of river valleys, fluvial activity is more important than temperature or precipitation. High fluvial-activity during wet periods suppresses forests within valleys and forms flood plain meadows. This becomes for many areas the only refugia for inhabitants of open habitats. In contrast, during periods of low fluvial-activity, valleys are occupied by trees, and ravine forests are formed. Because extensive areas of open habitats occur on the interfluves, valleys tend to be less attractive for steppe mammals. Small valleys are expected to follow this pattern most strictly (Popova, 2015).

River valleys can provide dispersal routes for ground squirrels (Ermakov and Titov, 2000). For example, S. odessanus recently penetrated the range of $S$. citellus along valleys of the Dniester and the Prut rivers (Zagorodnyuk, 2011). In this respect, phases of forest expansion acted as a 'pump' because suitable areas outside floodplains were drastically reduced. Whereas during cold phases, forested river valleys were effectively closed to steppe mammal dispersal. 
A further aspect concerns interactions between ground squirrels and large domestic herbivores, primarily cattle and horses. The zoological literature of the 19th and early 20th centuries documents many cases where agriculture has had an adverse effect on ground squirrel populations

(Zagorodnyuk, 2011). Invasions of Spermophilus into the new agricultural territories was recognised in early studies (Bielskiy, 1929). Pastured cattle are a significant factor in this respect. For example, a new ground squirrels settlement appeared near the village Kashino (Middle Trans-Urals, Russia) in the pasture of a new horse farm. And pasture degradation is believed to be responsible for the disappearance of the long-existing ground squirrel settlements near the Biological Station of the Ural Federal University. A further example is in the Volga region, where some ground squirrel colonies have disappeared due to the termination of pasturage in the surroundings (Kuzmin et al., 2011). The same mutualism between ground squirrels and ungulate grazers is evidenced by the failed reintroduction of $S$. odessanus in Kaniv Natural Reserve (Ukraine). According to the reserve researchers Polishko and Chornyi (pers. comm.), the reason for this failure being the dominance of tall grassland in a reserve where there are no steppe-adapted ungulates to maintain the type of lowgrass habitats favoured by ground squirrels. Similarly, the ecological conditions created by large hoofed-mammals help to explain the wide distribution and high population of ground squirrels in the Pleistocene of Europe.

The members of the genus Spermophilus possess a high ecological plasticity that allows them to maintain stable populations even in non-optimal environments. This applies to both the extant $S$. major in isolates surrounded by forest (Lemesh and Pogodina, 2010) and the extinct S. superciliosus during the Holocene in the Ukraine (Popova, 2015) and in the Middle Trans-Ural of Russia (Chemagina et al., 2016). This ecological plasticity may be connected with the coloniality. Colonial animals are characterized by patchy spatial distribution, and it is the best survival strategy to fit in a (from the ground squirrel point of view) harsh, but heterogeneous environment. Long-lasting populations surrounded by forest habitats evidence a maintained gene exchange with other populations.

Civil engineering infrastructure provides a means by which many animals can overcome natural constraints. For example, the isolated colonies of Spermophilus major on the right bank of the Volga River (Fig. 1d) appeared after the Saratov reservoir dam was built. The dam created the opportunity for the Trans-Volga fauna to cross to the right bank (Ermakov and Titov, 2000). Another case of dispersal aided by engineering infrastructure has been described by Ćosić et al. (2013) for S. citellus, which appears to have used bridges to cross the Tisza River. Generally, taking into consideration the presence of ground squirrel colonies in railway and road embankments (Gashev et al., 2012), modern ground squirrels are not necessarily timid animals that avoid human interference; the role of bridges in their dispersal seems to be supported by the available evidence. However, Ćosić et al. (2013) propose a more likely explanation for gene flow of $S$. citellus across the Tisza River, namely the recent straightening of the river to remove meanders that has resulted in 'relocating' of quite large areas of land from side of the river to the other.

This latter explanation applies also to natural situations where rivers have been crossed through the formation and cutting-off of river incised meanders to form oxbow lakes. We propose the term 'island crossing' for this mechanism, which embraces meander formation (Fig. 2.1), then a deep incision and the separation of these meanders from the river to form oxbow lakes (Fig. 2.2). The 'islands' created by this process, if occupied by ground squirrel colonies, would translocate the 
colonies from one side of the river to the other. Important determinants in this mechanism are primary relief and pre-Quaternary geological structure of the area, together with climatic conditions that support meandering rivers.
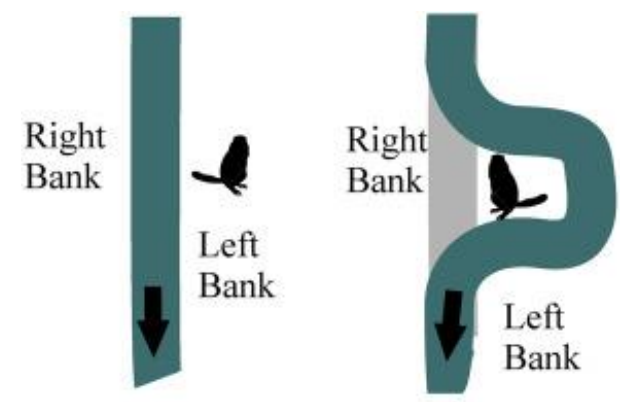

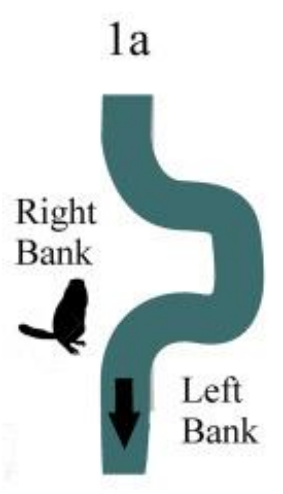

2a

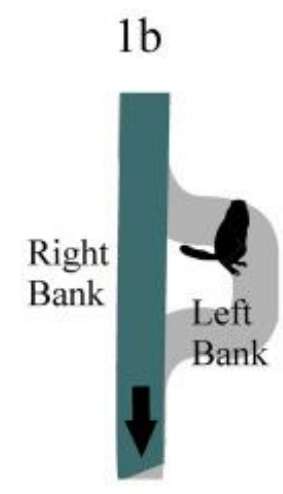

$2 b$

Fig. 2. Model for passive 'river crossing' utilizing 'islands' created during the formation (1) and cutting (2) of an oxbow lake.

\section{Source data}

We personally studied only a small part of the material discussed in this paper (see Appendix). The use of published data on fossil ground squirrels is therefore essential for the present paper. There are problems inherent in this approach, partly resulting from the burrowing habit of ground squirrels; their remains occur commonly in burrow taphocoenoses, and thus are younger than the sediments in which they are found. Old excavations often lack data on the potential presence of burrows; so, the presence of intrusive elements might affect the precision of the conclusions if the published dates of key specimens were incorrect. A more serious problem is the difficulty of establishing the veracity of taxonomic identifications of Spermophilus specimens, especially if the material is published in faunal lists only, without figures or descriptions. Examples of presumably misidentification are, in our opinion, records of Spermophilus undulatus (now Urocitellus undulatus) and S. major (or its junior synonym S. rufescens) in the Pleistocene of Europe (see compilations of Pleistocene rodents in Kowalski, 2001; Krokhmal' and Rekovets, 2010). The finds referred to 'S. undulatus' might be in fact S. primigenius (Reumer and Hoek Ostende, 2003), and those of $S$. major/rufescens are more likely to be S. superciliosus (Popova, 2016a). In both cases, the reason to reject the primary identifications is the same: there are large geographic gaps between the extant ranges of $U$. undulatus and $S$. major and the localities of the assigned fossil records, so that it is very unlikely that they expanded their ranges during the Pleistocene without leaving any trace in this 'gap area'. 
Fossil records with open nomenclature ('cf.', 'aff.', and 'ex gr.') have been treated as respective species in the maps, but maintain in their original form in the list of records (see Appendix).

Identifications to the generic level (Spermophilus sp.) have not been considered in the maps, except for particular cases discussed in the text.

When revising the taxonomy of Holarctic ground squirrels, Helgen et al. (2009) suggested using the former subgenus Urocitellus as a generic name. This was applied to the east and north Asiatic longtailed ground squirrels, U. undulatus and U. parryi. European Early Pleistocene Spermophilus species have been assigned to $S$. (Urocitellus) nogaici, S. (Urocitellus) primigenius and S. (Urocitellus) polonicus (Gromov et al., 1965). Attributing these fossil species 'automatically' to the genus Urocitellus would imply a close relation of these species to extant east and north Asiatic taxa. However, the exclusive European range of these fossil 'Urocitellus' finds is by no means evidence of affinity with east and north Asiatic long-tailed ground squirrels. The first appearance of the three fossil species (Fig. 3) is far more ancient than the latest trans-Beringian expansion event involving $U$. undulatus and U. parryi (Vorontsov and Lyapunova, 1976; Harrison et al., 2003). However, a final decision requires new detailed morphological comparisons between these fossils, and recent representatives of genera Spermophilus and Urocitellus. S. nogaici, S. primigenius and S. polonicus will be cited here as species of genus Spermophilus.
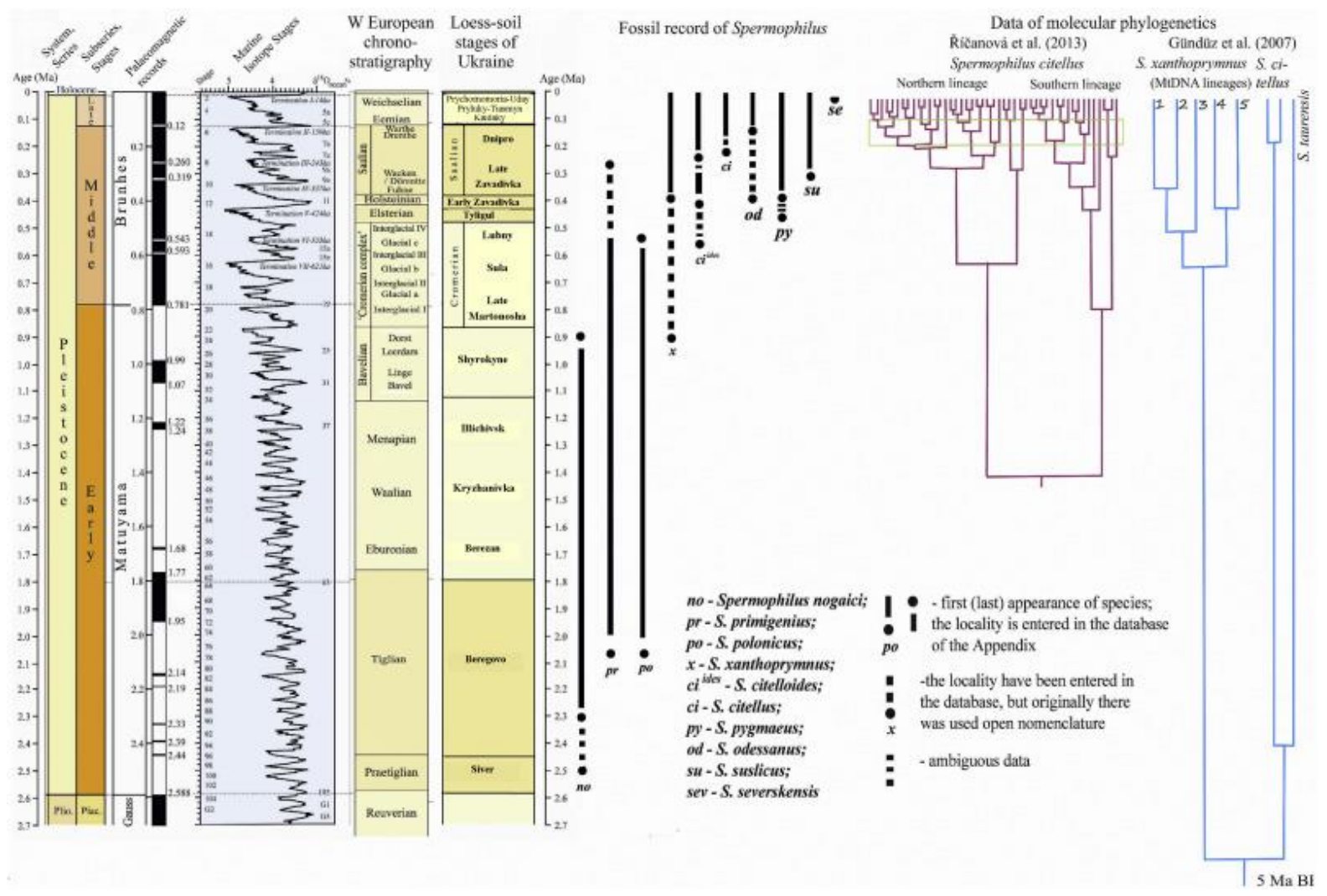

Fig. 3. Molecular phylogenies and stratigraphic ranges of ground squirrel species in the circum-Black Sea area based on fossil records and phylogeographic data and plotted against the global chronostratigraphical correlation table (Gibbard and Cohen, 2008)- Correlation between Ukrainian and West European charts is after Matviishyna et al. (2010). Information on fossil records corresponds to data in the Appendix. 
Normally, there is no sympatry of recent ground squirrel species. Occasional cases are of short duration only and are indicative for shifts of ranges in response to environmental changes (Kuzmin et al., 2011). However, as the fossil record shows, sympatry between the large $S$. superciliosus and smaller species (S. citelloides, S. severskensis, or S. odessanus) occurred in the past. This is in agreement with the rule of competitive exclusion (Hutchinson, 1959), because the size between $S$. superciliosus and any of the small species differs at least by a factor of $\sim 1$.3. Such size difference allows species to avoid interspecific competition, which is a key prerequisite in the formation of range boundaries. Large ground squirrels are not considered in this paper, but their records are presented in the database (Appendix).

\section{Palaeozoogeographical events in Spermophilus species}

\subsection{Spermophilus xanthoprymnus Bennet, 1835}

\subsubsection{Extant and fossil ranges}

The extant Spermophilus xanthoprymnus is distributed in Anatolia and along the Anatolian borders of Iran and Armenia (Gür and Gür, 2010). Unfortunately, the fossil record of this species is poor and its remains are uncommon until the Holocene (Gromov et al., 1965). Gür and Gür (2010) mention remains from the Early Pleistocene of Dursunlu, Turkey (Güleç et al., 1999), and the Middle Pleistocene of Chios Island, Greece (Storch, 1975), Karain Cave, Turkey (Storch, 1988) and Emirkaya2, Turkey (Montuire et al., 1994) (Fig. 5). Originally, the remains from Dursunlu and Emirkaya were identified as Spermophilus sp. Gür and Gür (2010) assume stability of the core habitats of S. xanthoprymnus in Asia Minor and conclude, these records probably represent this species because they are within the extant range of the Anatolian ground squirrel.
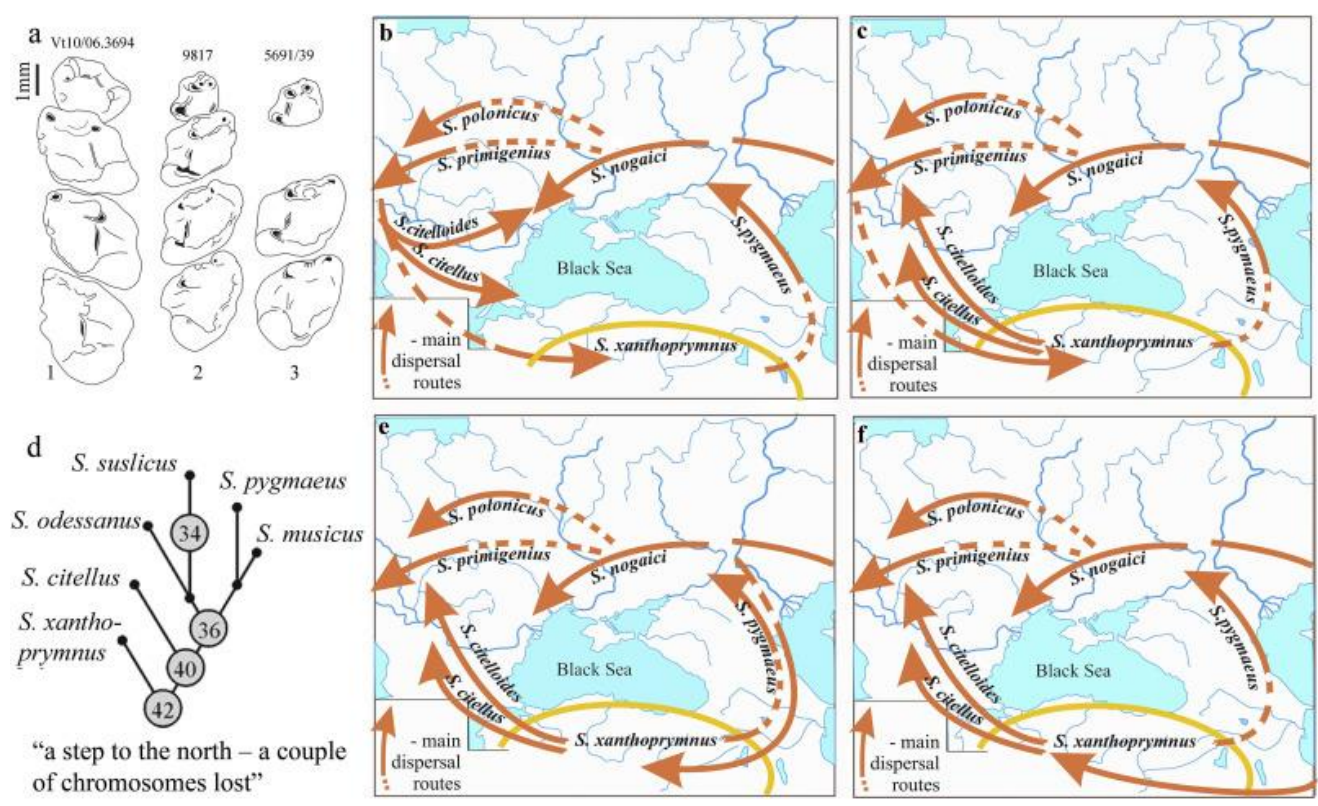

Fig. 4. Possible relatives of S. xanthoprymnus and scenarios of its appearance suggested by this affinity. (a) lower tooth rows of: (1) S. primigenius from Villány 3, Hungary (holotype); (2) recent S. xanthoprymnus; (3) recent $S$. citellus (incomplete tooth row), all juveniles, to simplify comparison. (b) scenario of origin of S. xanthoprymnus from S. primigenius; (c) the same scenario, retaining the Anatolian center of dispersal of recent species; (d) the phylogenetic relation of European ground 
squirrels proposed by Zagorodnyuk (2002) based on karyotype structure (chromosome numbers in circles); (e) scenario of origin of S. xanthoprymnus from S. nogaici; (f) scenario that meets the conditions of our model.
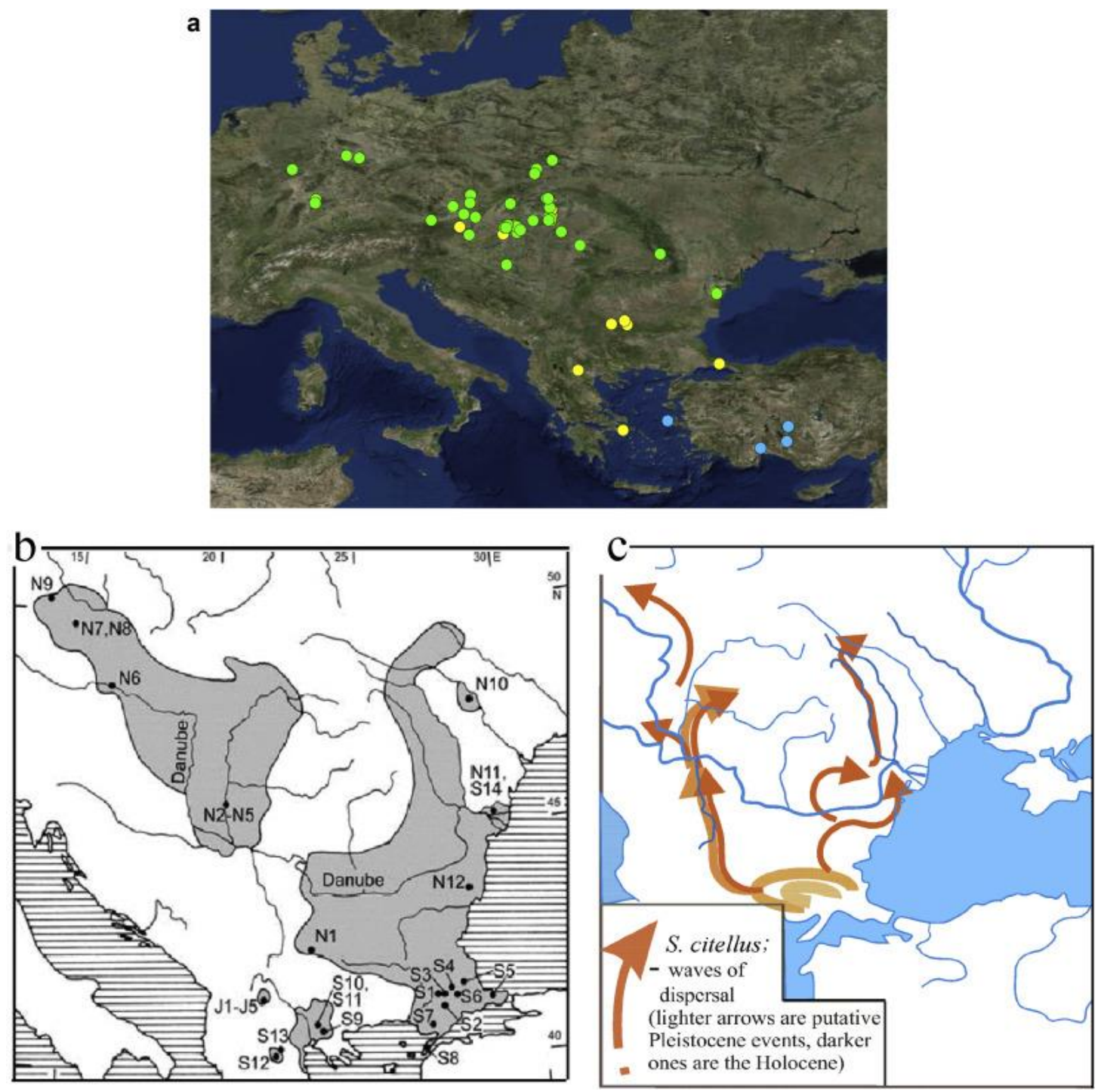

Fig. 5. (a) Fossil records of S. xanthoprymnus (blue circles), S. citellus (yellow circles), and S. citelloides (green circles), for source data see Appendix; (b) MtDNA lineage distribution in S. citellus (Kryštufek et al., 2009), N - Northern lineage (N1-12), S- Southern lineage (S1-14), J (J1-5) - Jakupica lineage, which can be considered as a part of the Southern lineage (Říčanová et al., 2013); (c) putative pathways of the expansion of S. citellus, based on Říčanová et al. (2013), but modified to accommodate fossil data. (For interpretation of the references to colour in this figure legend, the reader is referred to the web version of this article.)

Records of S. xanthoprymnus are all found within its present-day range. The absence of any other Pleistocene Spermophilus species in Anatolia is puzzling, particularly since Asia Minor is a hotspot of Spermophilus diversity and widely believed to be a center of dispersal.

\subsubsection{Phylogeny}


In previous phylogenetic reconstructions of Eurasian Spermophilus species (Vorontsov and Lyapunova, 1976; Zagorodnyuk, 2002; Gündüz et al., 2007; Popova, 2016b) S. xanthoprymnus is considered to be the most plesiomorphic member of this genus in Eurasia (Fig. 3). Fig. 4a illustrates the archaic occlusal surface of S. xanthoprymnus in comparison with the recent S. citellus. Although the extinct S. primigenius appears to be even more primitive (with unusually large premolars), its resemblance to S. xanthoprymnus is still significant. However, the hypothesis of an early appearance of S. xanthoprymnus, and of Anatolia as an center of dispersal for European Spermophilus (Gündüz et al., 2007) is not clear cut when tested against the fossil record.

The most ancient ground squirrel in Eastern Europe is S. cf. nogaici from the Khaprovian fauna Zhevakhova Gora-15, Ukraine (Stadnyk and Dema, 2007) dated to MN 17 (2.5-1.8 Ma BP) (Tesakov, 2004). The oldest Spermophilus records from Western Europe (S. primigenius from Villány 3 , Hungary and S. polonicus from Kamyk, Poland) are also from MN 17 respectively from earliest Biharian (Fig. 3). A further large sample of S. nogaici from the northern Black Sea area is dated to about 2 Ma BP (Tesakov, 2004). S. nogaici, S. primigenius and S. polonicus distinctly differ in their dental morphology (Gromov et al., 1965), and occupied well-separated geographic ranges. They are significantly more ancient than the earliest records of S. xanthoprymnus. We hope future palaeontological researches in Turkey will shed light on the relationship between S. xanthoprymnus and these extinct species.

\subsubsection{Dispersal events}

Ground squirrels originated in the New World and spread to Asia and then to Europe (e.g., Black, 1972; Vorontsov and Lyapunova, 1976; Harrison et al., 2003). As mentioned previously, the earliest Spermophilus records in Europe are known from MN 17 and thus older than the earliest records from Asia Minor. This would imply an Early Pleistocene expansion bypassing Anatolia (Fig. 4b and c), making Western Europe the center of dispersal for several extinct and extant species (Fig. 4b). This point of view is maintained by Ozkurt et al. (2007), in contrast to the aforementioned widely accepted ideas about diversification of ground squirrels.

If we retain Anatolia as the center of dispersal, so that an ancient species comes from Western Europe to Anatolia, where S. xanthoprymnus arises, and gives rise to S. citelloides, S. citellus etc, Fig. 4c), it would involve two or even three crossings of the Bosporus-Dardanelles, including a backdispersal from Asia Minor to Europe. Such returns to Europe would have been hindered by the presence of closely-related species there (as described above: competition between Spermophilus species is important in the formation of Spermophilus range boundaries not less than geographical barriers). Thus, too many special conditions would be necessary to allow for the scenarios in Fig. 4c, so that a European ancestry of S. xanthoprymnus seems to be less probable. Supposing an origin of S. xanthoprymnus from S. nogaici of the northern Black Sea area would cause almost the same difficulties (Fig. 4e). At the moment, the scenario of Fig. $4 \mathrm{f}$ seems to be preferable (till new findings of Early Pleistocene ground squirrels in Turkey or Iraq prove or disprove it).

The asynchronity between molecular and fossil data poses an additional problem (Fig. 3). The branching between $\mathrm{S}$. xanthoprymnus and a common ancestor of $\mathrm{S}$. taurensis and $\mathrm{S}$. citellus was estimated by Gündüz et al. (2007) at 5 Ma BP on the basis of a molecular clock analysis. This divergence time is clearly too old. S. orientalis Qiu, 1991, the oldest known Eurasian ground squirrel was found in China (Erteme, Inner Mongolia) dated to MN 13 (7.0-4.1 Ma BP). This species is 
atypical, being more similar to the North American AmmoSpermophilus or OtoSpermophilus (Qiu, 1991). The most ancient Spermophilus fossils in Europe so far are dated to $2.5 \mathrm{Ma}$ BP only.

Ages obtained from molecular clocks depend on the selection of fossils used for the calibration. If fossils are wrongly assigned to recent taxa instead of extinct ones (possibly unknown and as yet undescribed form), and if these data are used to calibrate phylogeographical results, the estimations of divergence time will necessarily be too old. It is always difficult to determine all representatives of a genus including the extinct ones, especially, when the genus includes representatives from three continents, as Spermophilus. Harrison et al. (2003), whose estimations of evolutionary rates were used by Gündüz et al. (2007), calibrated their results with records from the New World. In addition, Spermophilus in Harrison et al. (2003) still included North American Urocitellus representatives. All this can lead to overestimates of divergence times.

The youngest known demographic event in the Anatolian Ground Squirrel is a divergence of cyt b mtDNA lineages at 0.30-0.75 Ma BP, with most populations branching at 0.50-0.65 Ma BP (Gündüz et al., 2007). The disagreement with palaeontological data (Fig. 3) can be caused by the aforementioned calibration problems of the molecular clock.

\subsubsection{Range fluctuation}

Range extension during glacial, and range contraction during interglacials have been documented for several Spermophilus species, both extinct and extant (Agadjanian, 2006). Such dynamics in response to climate was reconstructed for S. xanthoprymnus by means of ecological niche modelling (Gür, 2013). The results show a geographical expansion of this species during the Late Glacial Maximum (LGM) extending westwards from the Sea of Marmara. Kryštufek and Vohralík, 2005 point to a shrinking of the range of S. xanthoprymnus proper from the Pleistocene to the Holocene. Similar range extensions in S. xanthoprymnus would be expected in earlier cold phases during the Pleistocene.

\subsection{Spermophilus citellus (Linnaeus, 1766)}

\subsubsection{Extant and fossil ranges}

The distribution of the extant $S$. citellus consists of disjunct areas between northwestern Czech Republic, Turkish Thrace and southwestern Ukraine (Ramos-Lara et al., 2014). The earliest S. citelluslike ground squirrel was described from the Middle Pleistocene Yaramburgaz Cave, Turkey (Santel and Koenigswald, 1998) with an age of 226 ka (cold interval within MIS 7, or late MIS 8 - Kuhn and Stiner, 2010). Other Pleistocene records are from younger sites (Santel and Koenigswald, 1998; Kowalski, 2001; Storch, 2004; Ramos-Lara et al., 2014, etc.) (Fig. 5a). Throughout the Middle and Late Pleistocene, a significant part of the present range of $S$. citellus was occupied by the extinct $S$. citelloides (see Fig. 5a and section 3.4). These closely-related species seem to be ecologically too similar (Jánossy, 1975; Gromov and Erbaeva, 1995) to have coexisted in sympatry. Despite morphometric differences (Heinrich, 1978), the morphological discrimination is difficult and some material previously identified as $S$. citellus is likely to include specimens identified as $S$. citelloides, as in the case of the material from La Adam, Gura Dobrogei, and Casian in Romania (Petculescu, 2013).

The relationship between S. citellus and S. citelloides is presumably a spatial and ecological vicariance, similar to the vicariance between extant S. pygmaeus and S. suslicus. Fossil records of $S$. 
citellus are mostly from southern Europe (Greece, Bulgaria, Romania, Serbia, Croatia, European Turkey), whereas most records of $S$. citelloides have been identified north of this area, with a possible zone of sympatry in Hungary (S. ex gr. citellus, Vértesszőlős, Hungary) (Kowalski, 2001).

\subsubsection{Phylogeny}

For the origin of S. citellus, three potential ancestors have been considered: S. citelloides (Kormos, 1916; Nadachowski, 1989; Gromov and Erbaeva, 1995; Kryštufek and Vohralík, 2005), S. primigenius (Gromov et al., 1965), or S. xanthoprymnus (Zagorodnyuk, 2002; Gündüz et al., 2007; Lyapunova, 2007). Both S. primigenius and S. citelloides were widespread in the Pleistocene of Europe, so that these ancestors would not cause difficulties with palaeogeographical barriers (Fig. 4b). In contrast, descendants of S. xanthoprymnus would require dispersal routes crossing the Bosporus. Although none of these three hypotheses can be completely excluded, the general direction of expansion looks rather clear, both on the basis of phylogeographical data and geographical distribution of fossil records (Fig. 5a, c): S. citellus, or its antecedent, dispersed from Asia Minor to southern and central Europe, which favours the hypothesis of an ancestry from S. xanthoprymnus.

Based on cytochrome b karyotype analysis and geometric morphometrics, Gündüz et al. (2007) suggest an origin for the group S. citellus-S. taurensis from S. xanthoprymnus (Fig. 3). This agrees with previous phylogenetical reconstructions (Vorontsov and Lyapunova, 1976; Zagorodnyuk, 2002) and morphological studies of the occlusal patterns of recent European Spermophilus species (Popova, 2016b): from these studies it is apparent that $S$. citellus is the most closely-related taxon to S. xanthoprymnus among extant European species (S. pygmaeus, S. odessanus, S. suslicus and S. citellus).

The branching between S. taurensis and S. citellus is dated by Gündüz et al. (2007) to $2.5 \mathrm{Ma}$ BP (Fig. 3). At this time Spermophilus already occurred in Europe. However, this was neither S. citellus nor $S$. xanthoprymnus, but S. primigenius (Fig. 3, Fig. 4a). Chronologically and morphologically, it is acceptable to suggest an origin for the $S$. citellus - S. taurensis clade from S. primigenius, given that the earliest (uncertain) records of $S$. citellus are those from the Middle Pleistocene sites of Vértesszőlős, Hungary (Fejfar and Heinrich, 1983; Jánossy, 1986; Kowalski, 2001), and Yaramburgaz Cave, Turkey (Santel and Koenigswald, 1998). However, the present range of S. taurensis (Tauras mountains in Anatolia - Gündüz et al., 2007) presumes this divergence to have taken place somewhere within Asia Minor, where S. primigenius has not been recorded to date.

\subsubsection{Dispersal events}

There are several circumstances that affected the immigration of the European Ground Squirrel from Asia Minor. One is the range expansion of Spermophilus xanthoprymnus during glacials (Gür, 2013). Another one is the state of isthmuses/sea channels, notably the Bosporus and Dardanelles with an intermittent connection between the Black Sea and the Marmara Sea during much of the Pleistocene (Meriç, 1995; Tchapalyga, 1995). These circumstances temporally allowed or blocked the spread of S. xanthoprymnus (or its descendant) into Europe. An isolation of this initial population, its subsequent adaptation to more mesophilous conditions eventually might have resulted in the origin of $S$. citellus. Of importance is possible presence of other ground squirrel species. The native ground squirrels might prevent invaders from establishing a viable population, a process that can be observed in the interspecific relationships between recent ground squirrel species (section 2). 
The appearance of $S$. citellus east of the Carpathian Mountains, is one of the latest dispersal events of this species. Our knowledge of this event is based on reliable palaeontological data, in contrast to most of the other more putatively dated events of the species history. Previously, the appearance of S. citellus in the Ukrainian area had been dated to the early Holocene (Gromov et al., 1965), but subsequently to the late Holocene (Gromov and Erbaeva, 1995). This is in agreement with recent data. There is no indication of a Pleistocene or early Holocene presence of S. citellus in Ukrainian or Moldova, nor in the northern Dobruja. Dobruja was occupied by S. citelloides (Petculescu, 2013), the southern Bug area by S. odessanus in the Middle Pleistocene (originally, S. suslicus s.l., Rekovets et al., 2007) and in the early Holocene (Popova, 2015), the Siret River basin by Spermophilus sp. (but not S. citellus) in the Late Pleistocene (MIS5-4) (Krajcarz et al., 2012), and many Pleistocene localities throughout Moldova and western Ukraine have yielded remains of S. suslicus s.I. (Gromov et al., 1965; Krokhmal' and Rekovets, 2010).

The Holocene expansion of $S$. citellus into the Pre-Carpathian area was presumably triggered by climate. In terms of climatic preferences, $S$. citellus is the most mesophilic of the Eurasian ground squirrel (Fig. 2). It would not have tolerated the severe and arid environmental conditions in western European areas during the Late Pleistocene glacial. During the Holocene, however, warmer conditions favoured the expansion of $S$. citellus to the north and to the east of its glacial refugium.

Valleys may have played an important role in the dispersal of this species. Under humid conditions, river valleys of the temperate zone provide important habitats for small steppe mammals. Meadows in valleys with an active watercourse may provide the only open habitats suitable for them to forage; valley meadows also serve as dispersal routes (see section 2). This effect increases when the environment beyond the valley floor becomes forested or unsuitable for other reasons. The Holocene humid environment might have forced S. citellus populations eastwards from the Walachian Plain, along valleys of the Prut (Gromov and Erbaeva, 1995), and the Siret rivers. Incised meanders are characteristic for these rivers, and cutting of the meanders could have provided the means by which ground squirrels crossed the river. Data of Říčanová et al. (2013) also indicate immigration of $S$. citellus from Romania to Moldova, but they date this event to at least $0.3 \mathrm{Ma}$ BP.

An argument for an alternative invasion route into the Pre-Carpathian area (through the Danube) can be found in Kryštufek et al. (2009). N11 and S14 haplotypes published in Kryštufek et al. (2009) (Fig. 5b) are located within Danube delta, Such a route isn't supported by the habitat preferences of ground squirrels, which avoid seasonally flooded deltas as they are unsuitable for their settlements. Going to the source data (from Gündüz et al., 2007) used by Kryštufek et al. (2009), it is clear that they plotted specimens N11 and S14 incorrectly within the delta, whereas both sites are located on the right bank of the Danube.

The Trans-Danubian invasion of S. citellus into the Walachian Plain is suggested by data both of Kryštufek et al. (2009) and Říčanová et al. (2013). Remarkably, being an ultimate barrier of recent gene flow (nuclear microsatellites), the Danube did not affect dispersal of mtDNA lineages (Kryštufek et al., 2009); Říčanová et al., 2013), although females, who pass mtDNA, have much lower dispersal rates than males. A possible explanation could be different time scales of events indicated by mtDNA and nuclear DNA markers (more ancient and more recent) (Říčanová et al., 2013). Thus, particular conditions or processes in the past facilitated ground squirrels to cross the Danube. Presumably they were similar to those, which recently facilitated ground squirrels to cross the Tisza River (Ćosić et al., 
2013), i.e., channel changes (migration of islands - section 2). Palaeo-islands (like those that exist on the Danube at present) could have served as bridges for ground squirrels: degradation of the left branch enabled expansion for a population previously isolated on the island. Indirectly this event can be dated to the Holocene on the basis of the absence of $S$. citellus in Dobrodgea until the Holocene (Petculescu, 2013).

Expansion of S. citellus to the northern part of the present-day range is documented solely from phylogeographical data (Kryštufek et al., 2009; Říčanová et al., 2013). Two main lineages of S. citellus can be discerned, a northern and southern one, both originating from Bulgaria. The southern group (with higher haplotype diversity and older age) was restricted to Bulgaria and Turkish Thrace for a long time. The northern group covers the major part of the present distribution of $S$. citellus as a result of several large-scale colonisation waves in two main directions: north-east to Romania/Moldova/Ukraine (see above) and north-west to Central Europe. All populations north of the Pannonian Basin (Czech Republic, Austria, Slovakia and Hungary) originate from a single colonisation event (Říčanová et al., 2013).

Leaving aside the issue of time estimations, the reconstruction of the European ground squirrel dispersion by Říčanová et al. (2013) is in good agreement with our hypothesis of a spatial vicariance between $S$. citelloides and S. citellus. The more ancient part of the range of $S$. citellus is in southern Europe. The northern group sensu Říčanová et al. (2013) now inhabits areas occupied in the Late Pleistocene by $S$. citelloides. This became possible after the extinction of the latter. Colonisation of the northern part of the present range by two branches of the northern group provides evidence for the isolation effect of the Carpathians. Consequently, conclusions of Kryštufek et al. (2009), who, in contrast, suggested that the Danube River and the Carpathians were not effective isolating and fragmenting populations of Pleistocene $S$. citellus, have been essentially modified by the later study of (Říčanová et al., 2013).

The role of river valleys as dispersal routes has been confirmed by Říčanová et al. (2013). Their data are so detailed that allow suggestion that the Morava valley was a connection between Macedonian populations of ground squirrels with those in Hungary and other populations at the north-western periphery of the species' range. Recently, both flooded and elevated islands near the Morava mouth of the Danube demonstrate different stages in the formation of meanders and oxbow lakes. This process occurred in the past and would have facilitated faunistical exchange between the right and the left banks of the Danube.

The time estimates provided by phylogeographers appear problematic. In section 4.1.3, we have suggested an explanation as to why the molecular clock may be too 'fast' for the expansion events in S. xanthoprymnus (Gündüz et al., 2007). The same applies to estimations of Kryštufek et al. (2009) because both teams used the same basis, i.e. the evolutionary rates suggested by Harrison et al. (2003). The age of the reconstructed events proposed by Říčanová et al. (2013) are significantly older than those of Kryštufek et al. (2009) and Gündüz et al. (2007) since Říčanová et al. (2013) chose Yaramburgaz Cave, Turkey as their calibration point. Putting aside the question as to whether it is acceptable to calibrate the molecular clock by a record identified as S. cf. citellus, this study used an incorrect age for the site. Říčanová et al. (2013) dated Yaramburgaz to 1.323-0.885 Ma BP, with a mean age of $1.104 \mathrm{Ma}$. This age range does not tally with those of Santel and Koenigswald (1998) or 
Kuhn and Stiner (2010) (see section 4.2.1) and is as much as four times older than the dates published by these authors for the critical deposits at Yaramburgaz Cave.

It is worth to consider how the conclusions of Gündüz et al. (2007), Kryštufek et al. (2009) and Říčanová et al. (2013) correspond to data on the Quaternary palaeogeography and fauna of Europe. Important inferences from the conclusions of these authors are: 1 ) because of similar divergence ages (0.5-0.3 Ma BP), presumably the same significant environmental change caused range splittings within S. xanthoprymnus and S. citellus; 2 ) despite several glacial cycles having elapsed since the branching, the isolated lineages have persisted; 3 ) i.e., the isolating factor must be something else, such as patchiness of forest and steppe habitats.

Říčanová et al. (2013) do not emphasize this surprising stability of DNA-mt lineages of the European ground squirrel in the face of the Quaternary climatic oscillations. But the problem, nevertheless, is the same as in the work of Kryštufek et al. (2009): Northern and southern groups have remained separated (i.e. stable) over several glacial/interglacial cycles. How was this achieved? The Pannonian refugium proposed by Říčanová et al. (2013), could provide a potential explanation for this phenomenon: Pannonia is rather isolated, but open to the northern-west periphery of the current $S$. citellus range (Fig. 5a); S. citellus of the Northern lineage could have survived glaciations in this region. This is supported by the fossil record of the Pleistocene S. citellus (Kowalski, 2001). However, it should be noted that Hungary is a region with numerous reliably identified samples of $S$. citelloides. Sympatry since the Middle Pleistocene would be extremely unlikely to have occurred for this long period of time with such closely related species as $S$. citelloides and S. citellus.

The very early branching of cyt b mtDNA lineages (Gündüz et al., 2007; Kryštufek et al., 2009; Říčanová et al., 2013) contradicts all palaeoecological and palaeogeographical data of Pleistocene mammalian communities. Isolation of mtDNA lineages would be the least probable, particularly since $0.5 \mathrm{Ma} \mathrm{BP}$, because of repetitive waves of climatically induced ecosystem changes that created the vast hyperzone with non-analogue habitats, such as steppe-tundra. Such an isolation runs counter to ground squirrel ecology and behaviour, in particular: (1) strict allopatry - Kryštufek et al. (2009) and Říčanová et al. (2013) reconstructed the Pleistocene range of S. citellus and superimposed it with ranges of S. citelloides and S. primigenius; (2) easy hybridization even between species - according to the cited authors even mt-DNA lineages were stable; (3) ecological plasticity, based on high ability to benefit from heterogenous landscape and resulting in active genetic exchange even between distant colonies - when, in the cited papers, an environmental patchiness is considered as a sufficiently isolating factor.

We propose the following solution that resolves these contradictions, namely to accept the phylogenetic tree constructed by the palaeogeographers but disregard the branching dates. As proposed by Kryštufek et al. (2009), a single event caused the contemporary differentiation of mtDNA lineages in both S. xanthoprymnus (Gündüz et al., 2007) and S. citellus. However, in our opinion, this event was the collapse of the Mammoth Steppe Biome that occurred at the end of the Pleistocene. This resulted, for S. xanthoprymnus, in a disintegration of the large Pleistocene range of this species (Gür, 2013), and, for S. citellus, in the expansion of the species into previously inaccessible areas.

Such an interpretation would be in good agreement with the Holocene geographical fragmentation of steppe species (Pidoplichko, 1954), and with available biostratigraphical data (Fig. 3). It is 
noteworthy that S. xanthoprymnus and S. citellus responded differently to Holocene landscape changes, with range expansion in S. citellus and range contraction in S. xanthoprymnus.

\subsection{Spermophilus citelloides Kormos, 1916}

\subsubsection{Fossil range}

The earliest record so far of the fossil species Spermophilus citelloides is from the Middle Pleistocene (Holsteinian) fauna of Tarkő in Hungary (Jánossy, 1962, 1976). During the Late Pleistocene, this species became widespread in Europe west of the Carpathians (Fig. 5a). Black and Kowalski (1974) considered the East European S. severskensis (see also section 3.7) to be a younger synonym of $S$. citelloides. For this reason, Kowalski (2001) in his compilation of Pleistocene rodents of Europe, transferred all records of $S$. severskensis into $S$. citelloides. However, we do not agree with this synonymisation. S. severskensis is a highly specialised form of the Late Pleistocene periglacial fauna of Northern Ukraine (Gromov et al., 1965; Rekovets, 1979, 1985; Popova, 2013). Gromov et al. (1965) described morphological differences between S. severskensis and S. citelloides based on their studies of large samples of both species. Moreover, the ranges of these two species are obviously separated. A dubious record of S. citelloides from Adzi-Koba Cave, Crimea (Kowalski, 2001) has been taken from an early paper of Gromov (1961) antedating the description of S. severskensis. Gromov et al. (1965) did not mention the Adzi-Koba material in the section on S. severskensis, probably because they considered these finds as insufficient for a firm determination. In her studies on Pleistocene faunas of Crimea, Markova (2011) found only remains of S. pygmaeus, but neither of S. citelloides nor of S. severkensis. Taking all this in consideration, the Carpathians appear to delimit the eastern range border of S. citelloides.

\subsubsection{Phylogeny}

Possible ancestors of Spermophilus citelloides are the same as those proposed above for S. citellus, i.e., S. xanthoprymnus, S. primigenius, or S. polonicus. Possible phylogenetical and ecological relations between S. citelloides and S. citellus have been discussed in section 3.3. Gromov et al. (1965) considered S. citelloides as a possible ancestor of S. suslicus (S. odessanus in our sense - see section 4.5). However, this hypothesis is now unlikely, because $S$. suslicus and $S$. citelloides appeared concurrently (Fig. 3). The earliest spotted ground squirrels (S. suslicus) were found in Zavadivka deposits (Ukrainian equivalent of Holsteinian) deposits at the Medzhibizh site in the southern Bug area (Povodyrenko and Rekovets, 2003).

\subsubsection{Dispersal events}

In fossil sites with co-occurrence of S. citelloides and S. superciliosus, the latter species dominated during cold, the former during relatively warmer phases (Black and Kowalski, 1974), which, however, does not mean that $S$. citelloides was a thermophilous element. The competitive success of $S$. superciliosus during colder conditions was due to its larger size, in accordance with Bergmann's rule. Similar relations of abundance under cold conditions have been observed in cases where $S$. superciliosus and S. severskensis co-occur (e.g., Rekovets, 1985, table 1, p. 18: large samples from the Late Pleistocene localities Novgorod-Severskiy, Chulatovo, and others).

Competitive interactions within the size class of $S$. citelloides, i.e., between S. citelloides and $S$. citellus, can be expected because of adjoining/overlapping geographic ranges (Fig. 6a), in a situation 
analogous to extant interactions between S. pygmaeus and S. suslicus. Accordingly, climatically induced oscillations of the boundary between the ranges of $S$. citellus and $S$. citelloides should be expected, with S. citelloides expanding to the south during glacials, and S. citellus expanding to north during interglacials.

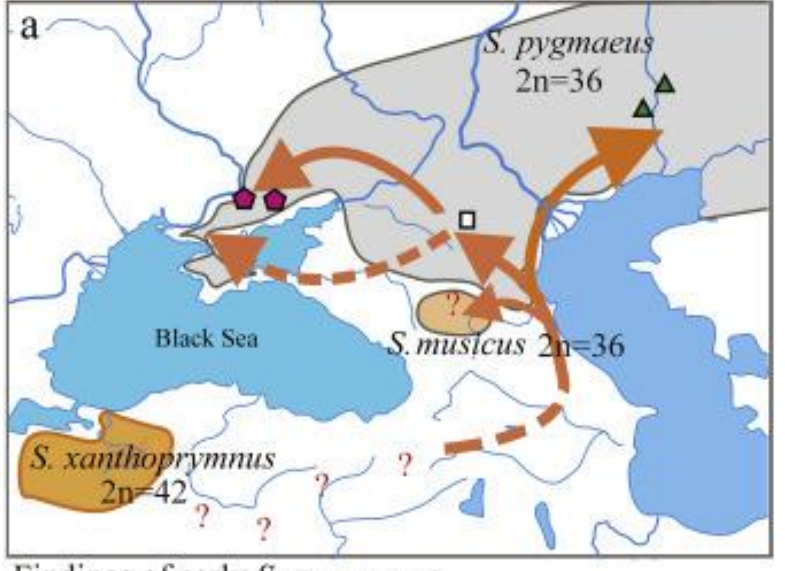

Findings of early $S$. pygmaeus:

Q - PreHolsteinian; 口-Holsteinian;

$\Delta$-Pygmaeus-like $S$, musicoides (Middle Pleistocene) -hypothetical waves of dispersal
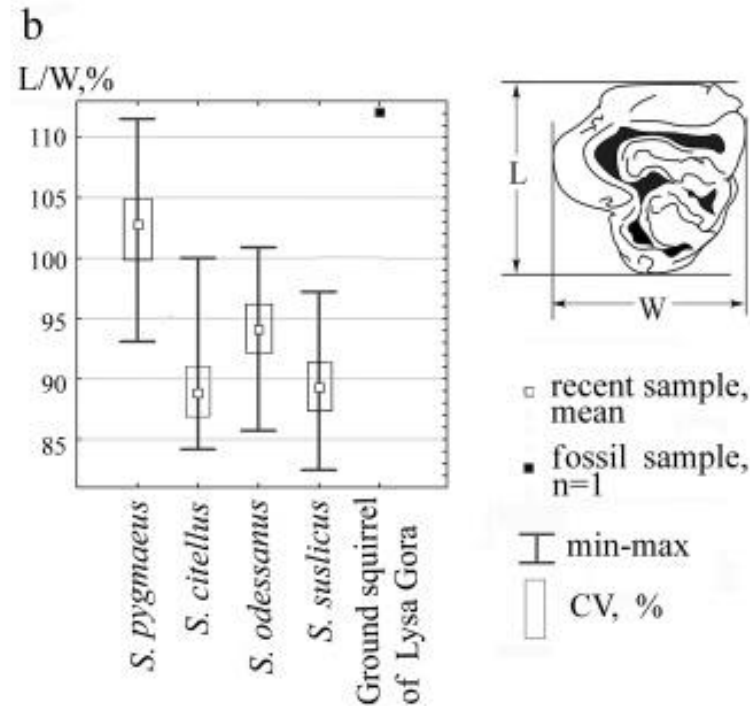

- recent sample, mean

- fossil sample,

I min-max

$\mathrm{CV}, \%$

Fig. 6. (a) Postulated expansion routes resulting in the appearance of S. pygmaeus; (b) Length/width ratio of M3 of Spermophilus from Lysa Gora, Ukraine and extant ground squirrel species from Europe.

\subsection{Spermophilus pygmaeus (Pallas, 1778)}

\subsubsection{Extant and fossil range}

The extant Spermophilus pygmaeus is distributed in plains or foothills, steppes and semi-deserts in the Dnieper Region (Ukraine), in the Lower Volga Region and in Cis-Caucasia (Dagestan, Russia); most of the range is in Central Asia east to the Aral Sea (Kazakhstan) (Tsytsulina et al., 2008).

Fossil molars of Spermophilus pygmaeus are easier to identify compared to all other extant ground squirrels of the northern Black Sea area (Gromov et al., 1965; Popova, 2016b). Pleistocene records of this species are known within its present range, in Terek-Kuma Lowland since the Holsteinian (Bolikhovskaya et al., 2015), and on the Crimean peninsula since the Eemian (Markova, 2011). The finds from the early Tiraspolian (Elsterian) fauna of Lysa Gora, Ukraine and in the northern Azov Sea area were referred to S. cf. suslicus by Rekovets et al. (2014), but more likely they belong to $S$. pygmaeus. This can be deduced from the following diagnostic characters (cf. Gromov et al., 1965; Rekovets, 1979): lower premolar is unshortened and has a reduced hypoconid; M3 is relatively longer and has a better-developed metaloph than in S. suslicus and S. odessanus. The M3 length/width ratio (113.2\%, $n=2$, measurements taken from Rekovets et al., 2014) compared with data of recent European species (Fig. 6b) supports the referral of the Lysa Gora specimens to $S$. pygmaeus. Although some morphological features that are characteristic for S. suslicus are observed, these may be due to the high percentage of old individuals with worn teeth, resulting in so-called 'age lophodonty' (Popova, 2016b). Also, one P4 occurs with a metaconule merged with a protocone that is not characteristic for S. pygmaeus. However, the characters of M3 and P4 seem to be diagnostically more important. Lysa Gora, Ukraine is situated at the left bank of the Dnieper and 
is correlated with the final phase of the Tiraspolian Faunal complex (MIS 13-12) (Rekovets et al., 2014), so that it is the oldest record of S. pygmaeus within its modern range (Fig. 3, the initial dot on the pygmaeus lineage).

\subsubsection{Phylogeny}

The earliest stage of S. pygmaeus evolution can be inferred from the finds of Spermophilus musicoides (Gromov, 1957) from sites along the middle and lower courses of the Ural River. S. musicoides is morphologically intermediate between the Caucasian S. musicus and S. pygmaeus. Unfortunately, the stratigraphic provenance of the material is uncertain. It originated from a recent channel alluvium of the Ural River and was accompanied by a unambiguous S. pygmaeus (Gromov et al., 1965). Thus, S. musicoides could be interpreted as an early form of S. pygmaeus. In any case, this material displays affinity between S. pygmaeus and S. musicus, and thereby, suggests a Caucasian origin of S. pygmaeus.

The taxonomical status of S. musicus is disputed. Recently, Tsvirka and Korablev (2014) provided karyotypic proofs that S. musicus is a valid species, but Ermakov et al. (2006b) considered it to be a subspecies (S. pygmaeus musicus), and derived a divergence of $4 \mathrm{ka}$ BP for the split between the two subspecies. The basis for this estimation incorporated palaeogeographical events and ecological properties of the Pleistocene environment of the Caucasus. Their conclusions conflict, however, with the presence of S. musicus sviridenkoi from the Middle or early Late Pleistocene of the Lagonaki plateau in the Caucasus, at $1500 \mathrm{~m}$ above sea level (Gromov et al., 1965).

What Ermakov et al. (2006b) had, in fact, shown, was not the taxonomic status of S. musicus, but the fact that the genetic distance between S. musicus and S. pygmeus is comparable with the distance between populations of $S$. pygmaeus from the right and the left banks of the Volga, as well as between S. odessanus and S. suslicus of the right and left banks of the Dnieper, and between $S$. fulvus and S. major. This fact is remarkable. S. pygmaeus from the right and the left bank of the Volga are morphologically similar and their conspecific status has never been in doubt, whereas spotted ground squirrels (S. suslicus and S. odessanus) from the right and left banks of the Dnieper are morphologically distinct (Filipchuk et al., 2005; Popova, 2016b), and appear to have been separated since at least the Middle Pleistocene (Fig. 3). Finally, although the branching between $S$. fulvus and S. major is very recent, morphologically they are readily distinguishable species (Gromov et al., 1965).

\subsubsection{Dispersal events}

The peri-Caucasian route of the ancestor (presumably S. xanthoprymnus) of Spermophilus pygmaeus is the most reasonable explanation for the appearance of S. pygmaeus in the northern Black Sea area. During the Pleistocene, the Caucasus underwent tectonic uplift reflected by a sequence of marine terraces (the highest of which is at $155 \mathrm{~m}$ above sea level). Besides, Ponto-Caspian regressions opened free passage across the exposed shelf (Zubakov, 1986; Veklich, 1989). Together with river terraces, this might have formed a system of corridors for faunal migrations. Dry steppe conditions during cold stages favoured faunistic exchanges between Cis- and Trans-Caucasia.

This expansion route would lead to the appearance of S. pygmaeus in Cis-Caucasia. Remains of early S. pygmaeus are still too few to discern stages of dispersal. However, certain records (Fig. 3) from 
the Holsteinian site of Otkaznoe (Bolikhovskaya et al., 2015) generally support the peri-Caucasian route. An eastern trans-Volga branch of expansion (as in Fig. 6a) can be implied from the significant genetical distance between $S$. pygmaeus populations of the right and the left bank of the Volga River (Ermakov et al., 2006b), and from the early occurrence of the ancient member of the lineage, $\mathrm{S}$. musicoides, in the Ural River area.

The Dnieper crossing is evidenced by a temporary presence of a S. pygmeus population on the Dnieper right bank. The first hints of such possibility came from zoologists, who described a new, pygmaeus-like subspecies of the spotted ground squirrel, S. odessanus boristenicus (Puzanov, 1958) that implies hybridization between S. odessanus and S. pygmaeus (Zagorodnyuk, 2011). Subsequently, a fossil ground squirrel from the Dnieper right bank (locality Sholokhovo) was identified as S. pygmaeus (Rekovets, 1979). New study of the Sholokhovo material confirms the presence of S. pygmaeus. By the time of the existence of the Sholokhovo fauna, it already was a hybrid colony since the population of $S$. pygmeus was in the process of being overrun by $S$. odessanus, which colonised this part of the $S$. pygmaeus range under the conditions of increasing climatic humidity (probably, during the Atlantic period of the Holocene) (Popova, 2015). This led to the extinction S. pygmaeus populations on the right bank of the Dnieper.

One possible route by which S. pygmaeus was able to reach the right bank of the Dnieper is north of Sholokhovo. Here the rivers Ros', Fosa and Vil'shanka form one loop, and the Irdynka, Irdyn' and Tiasmyn form another. Geologically, these loops correspond to big projections of the crystalline basement of the Ukrainian Shield that was a natural limit constraining the westward shift of the river (Dmitriev, 1938). The two loops are separated by a glacial landscape form known as the Moshnogorskiy Ridge (Fig. 6a). Such glacial dislocations within the Dnieper area usually correspond to the projections of the rock basement (Sobolev, 1926; Dmitriev, 1938; Lavrushyn and Chugunnyi, 1982).

The geological structure (Fig. 7, Fig. 8), associated landscape features and the composition of herbaceous vegetation within these loops are distinctly different from the those of other right bank areas, and show a strong resemblance to the opposite bank of the river (Bortniak et al., 1991). Moreover, the Irdyn' River (a tributary of the Tiasmyn) and Irdynka River (a tributary of the Dnieper) constitute in effect, a single river-system that is peculiar with respect to their stream directions. This can be seen when the level of the Dnieper River rises and the direction of flow of the Irdynka reverses to the Irdyn' and Tiasmyn. It is evident that Irdyn', Irdynka and Tiasmyn (as well as the Ros', Fosa and Vil'shanka) inherited a 'dead channel', abandoned by the Dnieper. The area enclosed by the loops formerly belonged to the Dnieper left bank, and were attached to the right bank when the Dnieper cut off its meander loops. In this way, plants and animals species living on the left bank (including S. pygmaeus) might have crossed to the Dnieper right bank. Although the current northern boundary of S. pygmaeus lies about $200 \mathrm{~km}$ to the south, S. pygmaeus fossils from Savyntsi (early Holocene or terminal Late Pleistocene) (Popova, 2015) indicate that the range of the species reached the latitude of the Tiasmyn 'island', or even further south, during more xerophilous phases of the Pleistocene. 


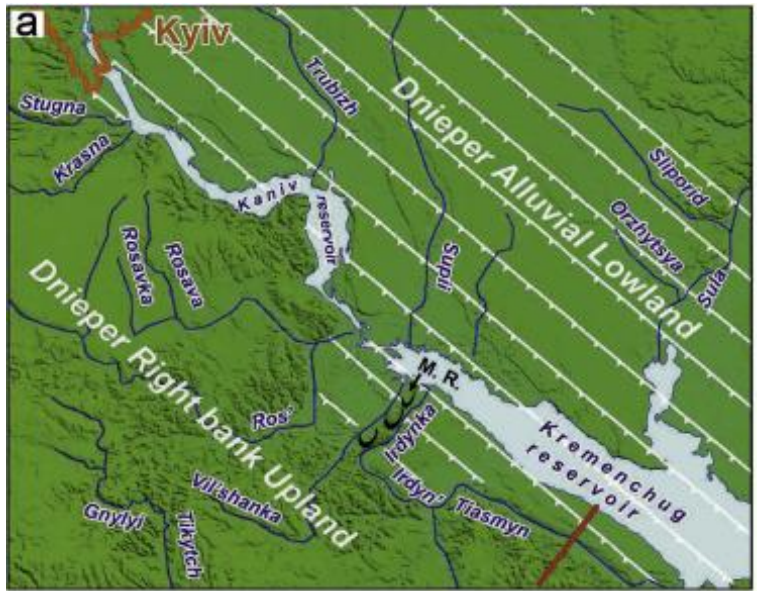

U M.R -glaciodislocations of Moshnogirskyi Ridge -geological profle through the "Tiasmyn island" (fig. 8)

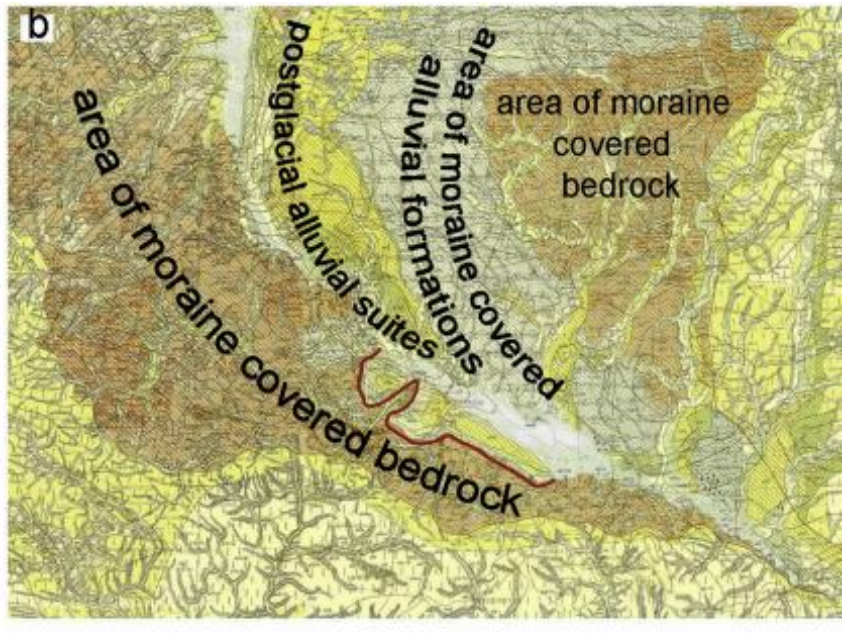

Fig. 7. 'Palaeo-islands' of the left bank relief and herbaceous vegetation within the Dnieper right bank area. (a) Landscape, and (b) main characters of the geological structure (after Veklich, 1977). 'Tiasmyn island' is indicated by the red line. (For interpretation of the references to colour in this figure legend, the reader is referred to the web version of this article.)

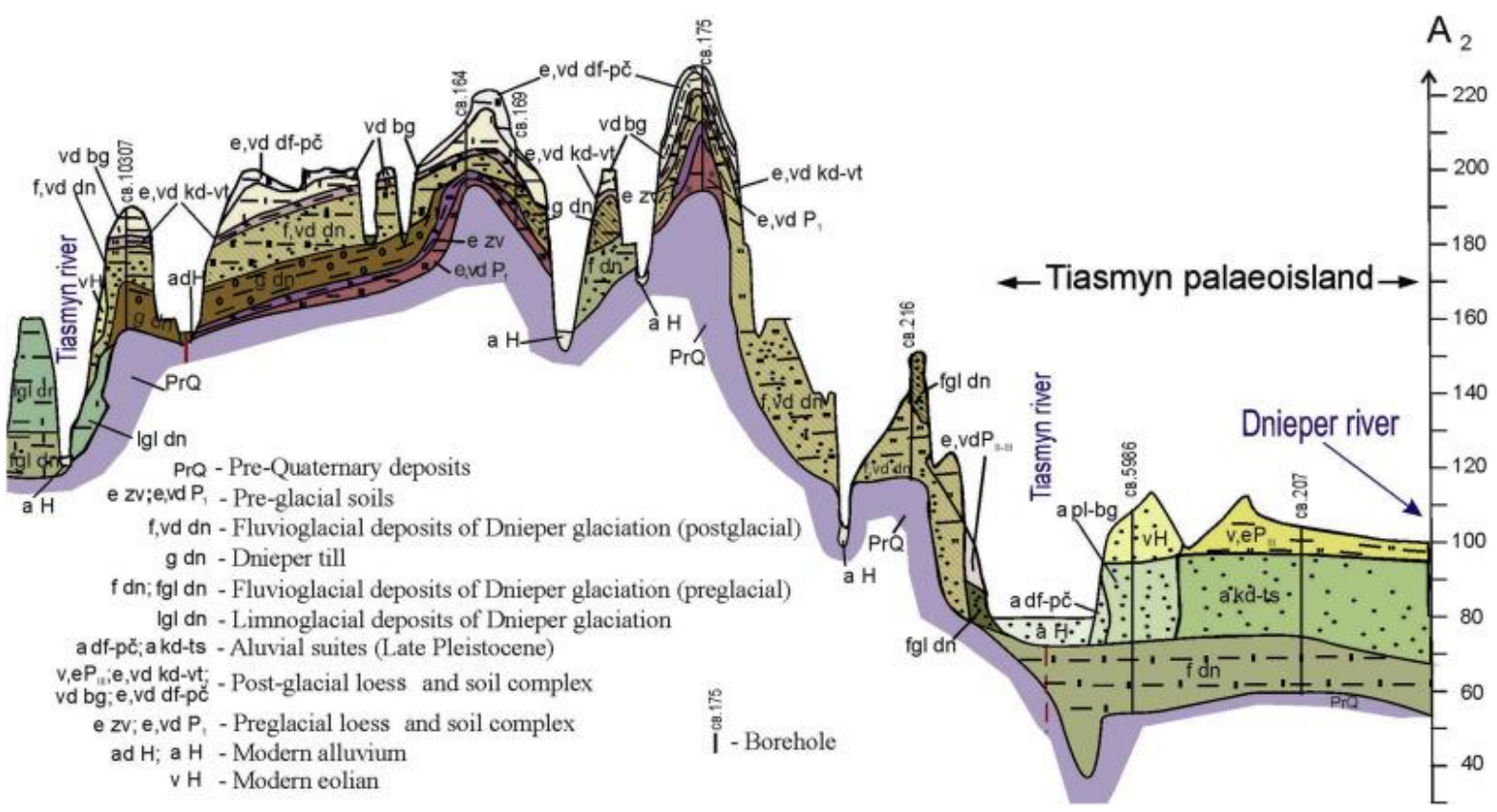

Fig. 8. Geological section through the Tiasmyn palaeo-island (State Geological Map of Ukraine, 2004) corresponding to the red line in Fig. 7a. (For interpretation of the references to colour in this figure legend, the reader is referred to the web version of this article.)

The timing of this transformation in the channel configuration can be estimated from the geological age of the alluvial suites that form the 'islands', namely by the formation of the youngest alluvial deposits of the palaeo-Dnieper, and the oldest sediments deposited by the Dnieper tributaries in the region. For example, authors of the State Geological Map of Ukraine (2004) estimate a MidPleistocene, post-Dnieprovian age (Kaidaky-Tiasmyn strata, kd-ts in Fig. 8), to the alluvial deposits that form the Tiasmyn palaeo-island (Fig. 8, see Fig. 3 for correlation with West European events). A significant amount of this alluvium was evidently deposited by the palaeo-Dnieper (not by the far 
smaller Tiasmyn). The next younger alluvial suite found there (Pryluky-Bug strata, pl-bg in Fig. 8) is likely to be formed by the Dnieper too because its thickness is also significant. Hence, the separation of the incised meander had occurred after the Bug stage i. e., after the Last Glacial Maximum. Data of other authors suggest a post-LGM age of the event (Veklich, 1977; Matoshko et al., 2002).

As an alternative to the peri-Caucasian route, the Tamanian-Kerchian route is suggested by the data on the possible early appearance of S. pygmaeus in the Sea of Azov area. This route has been proposed (an assumption on the basis of Rekovets et al., 2014) as the shortest route from the Caucasus to the Crimea, northern Azov area (Fig. 6a, broken line), but this hypothesis isn't without problems. The Strait of Kerch was a permanent mouth of the Don River at least since the Pliocene, persisting during both transgressions and regressions (Shnyukov et al., 1981).

Nevertheless, we propose this model, in order to stimulate a search of possible mechanisms, which may explain the dispersal pattern illustrated in Fig. 6a. Preconditions, which roughly coincided with the appearance of S. pygmaeus in the Azov area, might be: a) two canyon-like palaeo-valleys that have been traced on the floor of the Kerch Strait, alongside the both shores (Shnyukov et al., 1981). An elevation (island) between these valleys that could have served as a dispersal route between Taman and Kerch peninsulas, when sea-level fell as a result of either eustatic or tectonic movements. b) The palaeo-Don could have formed a dry megadelta, similar to that of the delta of the present-day Kuban River. The Kuban splits into several branches in its lower course. Such a quasi-delta would have transformed into the one-channel stream during periods of cold climate, but in contrast to most deltas, it did not flood. Under these conditions, the 'Island crossing mechanism' (Fig. 2) becomes possible. Further dispersion of S. pygmaeus to the north would have been unimpeded because, at about the time of the first appearance of this species within the Azov area (about 1 Ma BP, Fig. 3), the Sea of Azov did not exist in its current form (Shnyukov et al., 1981).

An alternative possibility is that $S$. pygmaeus is an autochthonous species of the cis-Caucasia steppe and the region bordering the northern Black Sea and Caspian Sea. S. pygmaeus may have evolved from S. nogaici, which then spread to populate Anatolia, later giving rise to S. xanthoprymnus. However, this hypothesis contradicts data on the ancestral position of S. xanthoprymnus among recent European Spermophilus (Vorontsov and Lyapunova, 1976; Zagorodnyuk, 2002; Popova, 2016b). More advanced S. pygmaeus may have originated from the archaic S. xanthoprymnus, but not the converse.

Palaeontologically, an autochtonous origin of S. pygmaeus from S. nogaici seems to be equally problematic. Finds that are dated to the period corresponding to the European Cromerian (i. e., between the last S. nogaici and first S. pygmaeus) (Fig. 4), do not clearly show a morphological linkage between S. nogaici and S. pygmaeus. Specialists in fossil ground squirrels of Eastern Europe (Rekovets, 1994; Markova, 2007; Agadjanian, 2009) refer fossil ground squirrels often to genus level only. It seems that the Late Tamanian and most of Tiraspol faunas rather represent a special stage of Spermophilus evolution.

A Central Asiatic origin of S. pygmaeus cannot be completely excluded because its modern range reaches the trans-Caspian areas, where it impinges on the ranges of such archaic species as $S$. erythrogenys and S. relictus. However, the above mentioned fossil finds (Rekovets et al., 2014; Bolikhovskaya et al., 2015) support the model presented in Fig. 6. 


\subsubsection{Range fluctuation}

During the Pleistocene and early Holocene, all known S. pygmaeus occur within the range of the extant species (Gromov et al., 1965; Markova, 2011; Rekovets et al., 2014; Bolikhovskaya et al., 2015), or close to it (for the Holocene, see Popova, 2015). However, by the analogy with the present, some Pleistocene changes of the species range in response to climatic oscillations appear likely.

\subsection{Spermophilus odessanus Nordmann, 1840 and Spermophilus suslicus (Güldenstädt, 1770)}

\subsubsection{Extant and fossil range}

Spermophilus suslicus sensu lato (or, sensu Gromov et al., 1965) has been recently subdivided into two species on the basis of the karyotypes and DNA sequencing: S. odessanus, with 36 chromosomes, and S. suslicus sensu stricto, with 34 chromosomes (Zagorodnyuk and Fedorchenko, 1995; Brandler et al., 2015). The morphological similarity of these species is the result of adaptations to similar ecological situations, rather than close phylogenetic affinity (Popova, 2016b).

In several paper (e.g. in the IUCN database; (Zagorodnyuk et al., 2008), the traditional taxonomy (viz. S. suslicus s. I.) is maintained because this organization recommends that authors to avoid taxonomic innovations. This does not mean a return to the previous taxonomic view. We consider the taxa $S$. odessanus and $S$. suslicus as separate species with their own distribution ranges and follow this view in this paper.

These species, 'the siblings separated by the Dnieper', are morphologically very similar, and were separated by this river likely throughout the time of their existence (Brandler et al., 2015). The validity of the two species has been proved by a multivariate analysis of cranial characters (Filipchuk et al., 2005). However, a reliable discrimination requires large samples. S. odessanus and S. suslicus display a clear resemblance in occlusal patterns with S. pygmaeus (Popova, 2015), which suggests an independent origin of S. suslicus and S. odessanus from S. pygmaeus rather than an ancestordescendant relationship between the two species.

\subsubsection{Phylogeny}

The origin of $S$. odessanus could be the result of a colonisation event of a Spermophilus population that crossed to the right bank of the Dnieper River. Such an introduction may have been favoured because there were no small-sized Spermophilus on the right bank of the Dnieper at this point. The probable age for this event is the Holsteinian; since then the spotted ground squirrel (identified as $\mathrm{S}$. cf. suslicus by Rekovets et al. (2007) has been present on the right bank the Dnieper (Fig. 3). The most ancient remains on the right bank that were identified as $S$. odessanus proper are dated to the late Middle Pleistocene (Saalian site of Khalepia - Popova, 2015). In addition to the above-mentioned examples, S. odessanus has been identified only from the Holocene burrow taphocoenosis at Kotovka (Popova, 2015). Other remains of small-sized ground squirrels from the right bank of the Dnieper were habitually (but in our opinion, wrongly) identified as $S$. suslicus (for a compilation see Krokhmal' and Rekovets, 2010).

S. suslicus seems to have appeared at nearly the same time (Holsteinian): remains identified as S. cf. suslicus are known both from both the left bank (locality Gun'ky - Rekovets, 1994) and right banks along the Dnieper (locality Medzhybizh, Ukraine - Rekovets et al., 2007). Such a synchronous 
appearance of both species may be accounted for by their 'grazing' feeding preferences (Popova, 2016b). The Holsteinian, with its warm and humid climate, provided optimal vegetational conditions for such feeding adaptations and allowed these specialised ground squirrels to establish themselves in Eastern Europe.

As with the origin of S. citellus from S. citelloides (section 4.2, 4.3 ), and S. severskensis from S. pygmaeus (section 4.6), the hypothesis of origin of S. suslicus sensu stricto from S. pygmaeus poses the question of sym-(para-)patric speciation. Peculiarities of interspecific competition in recent ground squirrels (section 2) and their easy hybridization impose especially significant restrictions on such sympatric speciation.

The present landscape does not display any obvious natural barriers between the ranges of $S$. pygmaeus and S. suslicus. Recently, these species have hybridized (Vorontsov and Lyapunova, 1969; Zagorodnyuk, 2002). The only isolating factor that can be suggested is a range fragmentation in $S$. pygmaeus under the condition of a humid and warm period during the Middle Pleistocene. This may have been followed by niche partition (i.e. separation of the niches of S. odessanus and S. pygmaeus that can be said comparatively broad). Further specialization of $S$. suslicus as a grass-eater facilitated expansion of its range to the north.

An alternative hypothesis is provided by Gromov et al. (1965) who assumed that $S$. suslicus originated from Late Pleistocene $S$. severskensis. This suggestion can be rejected because remains of spotted ground squirrels were subsequently identified in Middle Pleistocene (Holsteinian) deposits at Gun'ky, on the left bank of the Dnieper.

A further hypothesis is based on the idea of the integration of karyotypes, i.e., decrease of the chromosome number in Spermophilus in the course of their northwards expansion (Zagorodnyuk, 2002) (Fig. 4d); spotted ground squirrels came from Western Europe (S. citellus $\rightarrow$ S. odessanus $\rightarrow S$. suslicus). Although in general the decrease in the number of chromosomes in the course of ground squirrel expansions seems to agree with the surmises made on palaeontological, comparativemorphological and genetic basis (see Fig. 4, Fig. 6a), this phylogeny is problematic concerning the connection between $S$. citellus and $S$. odessanus because $S$. citellus lacks characters on the occlusal surface that are necessary to derive species-specific dental features of $S$. odessanus or $S$. suslicus (Popova, 2016b). And, in any case, the Dnieper crossing by the island crossing mechanism of Fig. 2 from east to west is far more probable than in opposite direction, because of the difference in the relief of the left (low) and right (high) bank of the Dnieper (Fig. 7, Fig. 8).

\subsubsection{Dispersal events}

Before the construction of the Dnieper reservoir system, 265 islands of different size occurred in the zone of the Dnieper rapids (Yavornitskij, 1990, pp. 53, 55, 57). Most of these islands are now submerged, together with their nearshore environments. As a result, the amount of currently available data concerning these islands is limited. Nevertheless, the following observations are pertinent:

1.

The majority of these islands were flooded every year. This would have made them unsuitable for ground squirrels to cross the river. The primary reason for this is that ground squirrels do not 
establish colonies in floodplains, and they invariably avoid floodplains associated with larger rivers. So these floodplain islands do not provide reliable 'stepping stones' for ground squirrels to cross the river at this point.

2.

Higher, unflooded islands existed mostly in the region of the Dnieper rapids. Among them, Khortytsia island was always the largest, and has a historical record that extends back to 946 and 953 BC when it was mentioned in ('De Administrando Imperio' of Emperor Constantine VII - cited by Repchenko, 1985). Although the granite which forms the core of Khortytsia Island has successfully resisted erosion and the island location has been being stable over several millennia, local toponymy is evidence that the island developed in the same way as Tiasmyn palaeo-island (see section 4.4.2): the right branch of the Dnieper is called the Old Dnieper.

3.

Joining of the left bank plots to the Dnieper right bank appears to be far more probable than the opposite situation. Although the Dnieper has shifted to the west (Fig. 7b) since the Middle Pleistocene Zavadivka stage (Holsteinian), the difference in the landscape and geological structure between the right and left banks (Fig. 8) channels the river through high and resistant bedrock of the right bank far less probable than through the alluvial plain of the lower left bank. So, the left bank areas are more probable to be cut off.

4.

All the aforementioned are actualistic arguments, to develop a hypothesis of the colonisation route for S. odessanus. As it has been shown by different authors (Goretskiy, 1970; Matoshko et al., 2002, Fig. 5), alluvial sequences of the Dnieper River older than the fourth terrace (Holsteinian), are incised up to $20 \mathrm{~m}$ deeper than the bottom of the Holocene fluvial deposits. Palaeolandscapes, contemporary to these events, are now buried beneath the surface of the Dnieper alluvial plain.

\subsection{Spermophilus severskensis (Gromov et al., 1965)}

\subsubsection{Fossil range}

Spermophilus severskensis is an extinct species. Black and Kowalski (1974) believed that it is conspecific with S. citelloides (see section 4.3). However, S. severskensis differs from S. citelloides and all other Pleistocene ground squirrels of Europe by several unique features (Gromov et al., 1965; Rekovets, 1979, 1985; Popova, 2013). The species shows clear 'grazing' adaptations, such as an elongated hypoconid of P4 (Gromov et al., 1965), a particular occlusal pattern, and thickened enamel (Popova, 2013).

S. severskensis is known only from Late Palaeolithic sites of the Desna area (Rekovets, 1985). Fossil remains from the recent Dnieper alluvium, which had been previously assigned to $S$. severskensis (Gromov et al., 1965) have been re-classified as S. suslicus abbreviatus Rekovets, 1975 (Rekovets, 1979). The highly specialised S. severskensis was a species of the periglacial zone and went extinct without descendants (Rekovets, 1979). Among the Pleistocene ground squirrels, it had the narrowest geographical and stratigraphical range. 


\subsubsection{Phylogeny}

The origin of Spermophilus severskensis can not be implied unambiguously from tooth morphology since the dental characters of this species are intermediate between S. pygmaeus and S. suslicus (Popova, 2013). However, the palaeogeographical situation of the Late Pleistocene gives some hints. Climatic aridization during the Weichselian (in analogy to the current situation) caused range fragmentation in S. suslicus and range expansion to the north in S. pygmaeus (Fig. 9). These new northern areas were closer to the glacier, and, despite a general (global) aridization, they were watered better than typical habitats of $S$. pygmaeus, thus providing more opportunities for specialised grazers. This means in terms of niche division that the most specialised grazer of all Eurasian ground squirrels, S. severskensis, split off from the generalist S. pygmaeus.

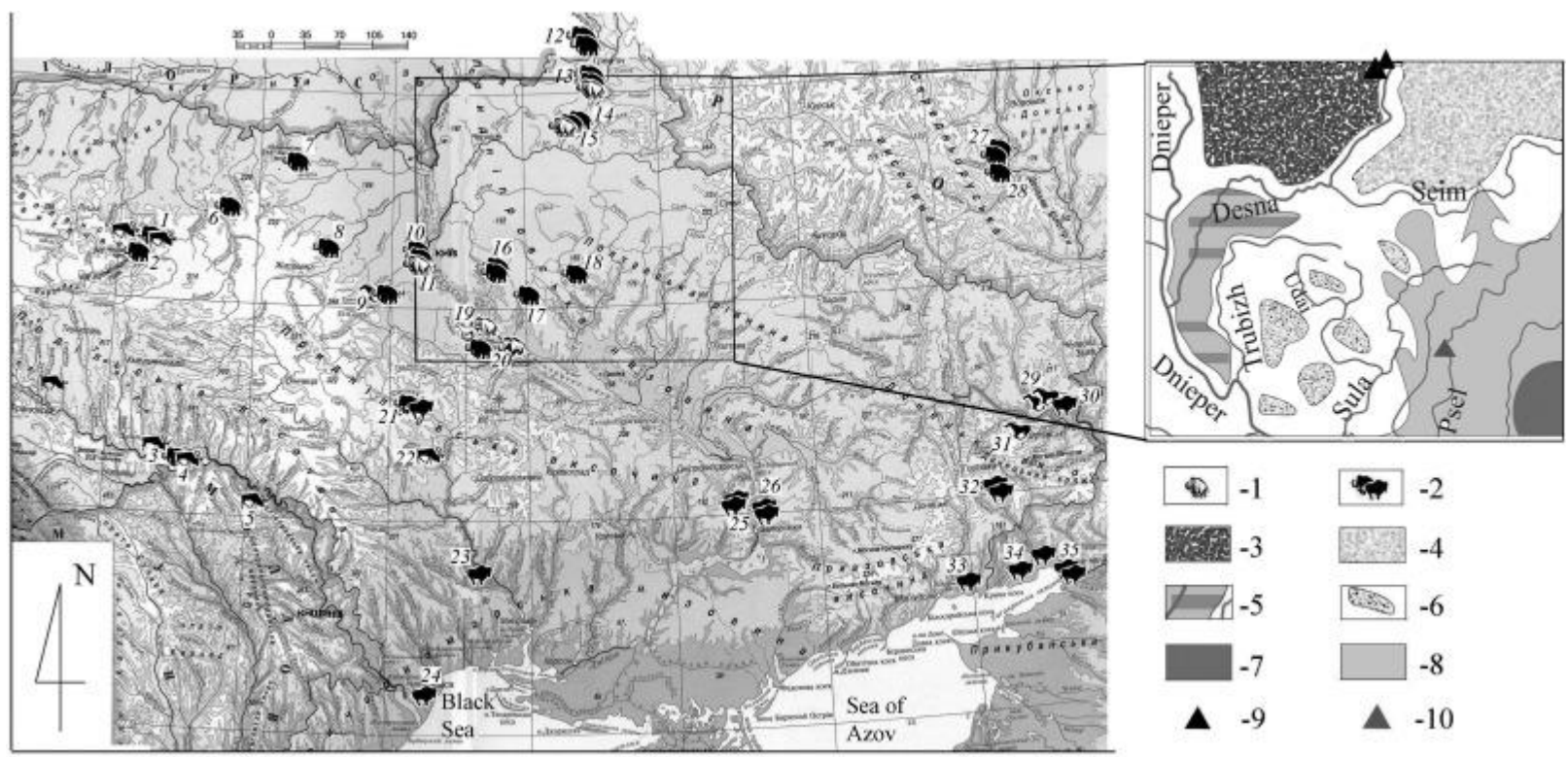

Fig. 9. The uninhabited region south of the Middle Desna, inferred from the distribution of Late Palaeolithic sites (20-13 ka BP) (Shydlovskyi, 2005a) and its interpretation on the basis of ground squirrel ranges. 1 - finds of main prey, not in archaeological context; 2 - finds of main prey from Late Palaeolithic sites; 3 - range of $S$. severskensis derived from fossil records; 4 - predicted range of $S$. severskensis, deduced from contemporary palaeogeographical and palaeozoogeographical situation; 5 - Dnieper-Desna-Trubizh unpopulated triangle; 6 - fragmented range of $S$. suslicus; 7 - present range of S. pygmaeus; 8 - expected range of S. pygmaeus during Last Glacial Maximum; 9 - fossil records of S. severskensis (Novgorod-Severskiy, Pushkari) (after Rekovets, 1985); 10 - late Pleistocene-early Holocene finds of S. pygmaeus (after Popova, 2015).

\subsubsection{Dispersal events}

The range of Spermophilus severskensis was restricted to the north by the periglacial zone, the conditions of which were beyond ground squirrels' abilities to adapt and cope with the severity of the climate. However, a clear southern barrier seems to have existed. All records are known from Late Palaeolithic sites of mammoth hunters. Although these Gravettian and Epigravettian Ukrainian sites (Mezhyrich, Dobranychivka, Hintsi, Mizyn and others) exhibit a dense cluster of localities in the Middle Dnieper region, a large, roughly triangular area between the Trubizh, Dnieper and Desna valleys (Fig. 9) appears to have remained unpopulated until the Neolithic (Shydlovskyi, 2005a). This 
'enigmatic triangle' appears to have been unsuitable for human habitation by hunter-gatherers (Shydlovskyi et al., 2016). Intriguingly, S. severskensis is not found in this region.

The absence of S. severskensis in the triangle between Trubizh, Dnieper and Desna is confirmed by faunas from the recent channel alluvium of the Dnieper. These assemblages comprises 2575 small mammal remains collected between Kyiv and Cherkassy, i. e., south from the Desna mouth (Topachevskij, 1961). They are heterochronous, and contain remains dating from between $100 \mathrm{ka}$ BP and the present (Popova, 2004). The absence of S. severskensis in these faunal assemblages is striking. Remains of other ground squirrel species are numerous, however, they belong to $S$. superciliosus and S. suslicus (Rekovets, 1979).

The nature of the southern range boundary is worthy of comment. In the area north of the 'enigmatic triangle', mammoth hunting continued until 11 ka BP (Germonpré et al., 2008; Khlopachev, 2014; Nuzhnyi and Shydlovskyi, 2015; Shydlovskyi et al., 2016), which is one of the latest examples of mammoth exploitation in temperate latitudes (cf. Stuart et al., 2002). The longterm survival of mammoth populations in the Desna area could have been due to peculiarities of the fluvial network. The confluence of the Dnieper and Desna, both fed by glaciers, could have caused water to discharge through the lowlands along the right bank of the Desna. Catastrophic floods, as proposed by Pazynych (2004) are not necessary conditions - moderate floods, even not yearly, might have been sufficient to modify the vegetation that would have provided suitable conditions for mammoths in this natural 'mammoth reserve'.

River floodplains provided important forage resources for mammoths (Ukraintseva, 1985; Shydlovskyi, 2005b). Similarly, aforementioned areas in the Trubizh-Dnieper-Desna triangle must have been attractive for these proboscideans, even more so when this area was not permanently populated by humans. For these reasons the Trubizh-Dnieper-Desna triangle provided a refuge for mammoths (Fig. 9), and sustain the economic base of Epigravettian mammoth hunters of the Desna and Dnieper in the adjacent areas. The mammoth populations helped to maintain the mammoth tundra-steppe ecosystem with plots of low grass that provided optimal conditions for S. severskensis in the Desna area.

An important aspect of the extinction of $S$. severskensis is that this species inhabited areas outside the sustainable Spermophilus range. Aridization during the LGM created this habitat for $S$. severskensis; this habitat collapsed with the Holocene warming. During the Preboreal, northern Ukraine became covered by birch and coniferous forests. The latest possible date of extinction of $S$. severskensis is the beginning of the Atlantic, when forests spread to their maximum extent on the East European Plain (Bezusko et al., 2008). The conditions that led to the extinction of this species are likely to have been factors in the demise of the mammoth and of mammoth hunters in the Dnieper and Desna areas. As discussed above (section 2) expansion/extinction events in modern ground squirrels are correlated with the appearance/disappearance of large ungulates in modern agricultural and natural ecosystems. Thus, the synchronous extinction of $S$. severskensis and degradation of mammoth ecosystems seem to be related phenomenon.

\section{Conclusions}

In this paper we reviewed the range dynamics of several smaller-sized European ground squirrels of the genus Spermophilus during the Quaternary. We considered the ecological background and 
palaeontological and other information pertaining to the changing geographical ranges of these species of ground squirrels; environmental changes that might have driven these colonisation and extinction events during the Pleistocene and Holocene were also discussed.

The combination of a burrowing lifestyle, hibernation, coloniality, and interspecific competition are critical factors in this discussion. For example, the presence of a colony of another Spermophilus species may be an insurmountable obstacle even if geographical or climatic barriers would be principally surmountable. Interspecific interactions provide the main explanation for the relatively high degree of allopatry in Spermophilus. These factors operate in concert with geographical barriers, or with interactions at the boundaries with other Spermophilus species. Present-day deviations from this pattern are, in our opinion, primarily due to human activity, particularly those resulting from agricultural practices, such as cereal cultivation. This provides abundant food, but at the same time results in a reduction in suitable ground squirrel habitats.

Thus, ecological and geographical vicariance would appear to be the common interspecific interaction in the adaptive zone of ground squirrels living under natural conditions in undamaged ecosystems. We use the analogy of a 'patchwork quilt' to characterise this distribution pattern in Spermophilus species. Sympatry between large-sized (e.g., Spermophilus superciliosus) and smallsized (e.g, S. citelloides) ground squirrels does not contradict the pattern, since increasing size differences tends to lower their interspecific competition. Therefore, large ground squirrels form another 'quilt' that overprints the ranges of the smaller species; this pattern requires a separate model, which is beyond scope of the present study.

Our 'patchwork quilt' model recognises two main types of borders separating ground squirrel ranges. The first type includes broadly 'subparallel' boundaries that oscillate as a result of ecological conditions, which influenced the level of competition between species. The second type consists of roughly 'submeridional' range boundaries that coincide with geographical barriers, such as water barriers and mountain ridges. Compared to climatically controlled boundaries, these topographic barriers tend to be rather stable over Quaternary timescales. Overcoming either 'subparallel' or 'submeridional' limits is therefore a proxy for landscape and environmental transformations. Where such populations have become isolated the possibility exists for evolutionary changes that may lead to the formation of a new taxon (species, subspecies).

Although currently available palaeontological data does not provide any new insights in to the phylogeny of ground squirrels, these data can, nevertheless, be exploited to investigate aspects of ground squirrel dispersal. Previously published data note:

1) an east to west immigration of ground squirrels from North America to Eurasia,

2) the ancestral position of Anatolian ground squirrels that diverged to form two major branches: a western European branch with S. citellus and S. citelloides, and an eastern European branch represented by S. pygmaeus. The latter branch gave rise to S. odessanus, S. suslicus and S. severskensis,

3) a western and eastern European ground squirrel dichotomy separated by the Carpathian Mountains. This barrier held throughout the Pleistocene, with only S. citellus crossing much later, during the Holocene, 
4) in eastern Europe, large rivers (e.g. Dnieper, Volga) formed often impenetrable barriers, as evidenced by palaeontological data. Crossing these barriers appears to be connected with palaeogeographical events,

5) in western Europe, at least two species (S. citelloides and S. citellus) were able to cross the less effective barrier of the Danube.

Examples of 'subparallel events' (from recent to ancient, and from more to less certain) are: repeated climatically driven oscillations of range boundaries between S. pygmaeus and S. suslicus; the Holocene immigration of $S$. citellus into the Pre-Carpathian area; the Late Pleistocene appearance of S. severskensis and (in the Late or Middle Pleistocene) of its west-European ecological analogue, S. citelloides; the branching of S. suslicus from S. pygmaeus before the Zavadivka (Holsteinian) Interglacial. A crucial feature of 'subparallel events' is that they are driven by climatic factors.

Examples of 'submeridional events' are: the apparently repeated crossing of the Danube by $S$. citellus; the appearance of an isolated population of S. pygmaeus on the right bank of the Dnieper during the Late Pleistocene to Middle Holocene; a crossing of the Dnieper by S. pygmaeus, which resulted in the appearance of $S$. odessanus before the Zavadivka stage (Holsteinian); the Middle Pleistocene intrusion of eastern populations of S. pygmaeus into the Trans-Volga areas. A rather hypothetical event is the 'Anatolian radiation', an Early Pleistocene divergence of the main western and eastern European lineages of ground squirrels. 'Submeridional events' appear to have been triggered by river channel changes and marine regressions that opened temporal migration corridors for ground squirrel species. During 'submeridional events' the probability of successful intrusion and speciation is lower when the potential area of immigration is occupied by another competitor ground squirrel species.

As it has been shown by the example of the 'empty triangle' between Trubizh, Dnieper and Desna rivers, spatial distribution of both the Palaeolithic human and ground squirrel settlements might be effectively controlled by a very complex (and overlapping) set of factors. It was not unexpected that human habitat preferences and responses to the environment challenges partly coincided with those of ground squirrels, who are also social, colonial and strongly competitive to relative species, and, respond on environmental constraints in more unambiguous way. The presented patchwork quilt model is very simple; however, it describes quite satisfactory the effects of environmental constraints on ground squirrel distribution and speciation. Inferences drawn from the model can help when considering other, more entangled cases, like dispersal events, replacements of species, and abandonment of territories with unfavorable conditions of other mammals, and on the first place, of human populations. Changes of species ranges in ground squirrels can be used as a criterion indicating the geographical barrier change.

In its present state, the 'patchwork quilt' model of ground squirrel range dynamics requires testing against a wider dataset of reliably-identified fossil material. Our understanding of range dynamics during the Early and Middle Pleistocene is also hampered by gaps in the record, most notably the very low number of fossil Spermophilus remains from Anatolia, the assumed 'center of dispersal'. Further research focussing on the Quaternary history and geomorphology of the Danube River will help to elucidate how ground squirrels were able to make repeated crossings of the river during the 
Pleistocene. These are a few of the questions that will guide future research into the biogeography of this fascinating group of rodents.

\section{Acknowledgements}

The authors are greatly indebted to V.L. Shevchyk (Kaniv Nature Reserve, Ukraine), who helped us to understand the importance of the Dnieper channel history in the vicinity of the Kaniv Nature Reserve. We are indebted to H. Gur, O. Erdal and O. Özkurt for discussion on fossil records of Spermophilus xanthoprymnus. Authors thank the reviewer K. Bogicevic for her helpful remarks. This paper is a contribution to INQUA Projects 1501 'Evolution of Ground Squirrels (Spermophilus) and the Late-Mid Quaternary Environment of the Northern Black Sea Area: Ground Squirrels on the March' and 1606: 'Ground Squirrels on the March: Expansion and Speciation in the Quaternary of the Circum-Pontic Area and Surroundings'. Simon Parfitt's contribution was made possible by a grant from the Calleva Foundation. L.V. Popova's and K.M. Bondar's work on this study is partly supported by the Department of Research and Development of Taras Shevchenko National University of Kyiv, grants 16БФ049-01 and 16БП049-0 of the Ministry of Education and Science of Ukraine. Natalia Pogodina's contribution was made possible by Act 211 of the Government of the Russian Federation, contract no. 02.A03.21.0006.

\section{References}

A.K. Agadjanian, 2006. [Stages of evolution of ground squirrels of northern Eurasia]. Bulletin of Moscow society of naturalists Biol. Ser., 111 (5), pp. 4-17 (in Russian with English summary).

A.K. Agadjanian, 2009. Melkie Mlekopitayushchie Pliotsen-plejstotsena Russkoj Ravniny [Small Mammals of the Plio-pleistocene of the Russian Plain]. Nauka, Moskva.

L. Bezusko, S. Mosyakin, A. Bezusko, A. Mosyakin, 2008. History of formation of the plant cover of the forest zone of Ukraine in the Late Glacial and Holocene (based on palynological evidence).

E.Y. Novenko, I.I. Spasskaya, A.V. Olchev (Eds.), 2008. Man and Environment in forest Zone: Past, Present and Future. International Conference, July 24-29, 2008. Moscow, Institute of Geography RAS, Central Forest State Natural Biosphere Reserve, Russia, pp. 15-16.

B. Bielskiy, 1929. Distribution of great jerboa (Allactaga jaculus Pall. $=a$. Salient $\mathrm{Gm}$.) within the left bank Ukraine. Proc. Phys.-Math. Sect. All-Ukrainian Acad. Sci., 13 (1), pp. 147-180

C.C. Black, 1972. Holarctic evolution and dispersal of squirrels (Rodentia, Sciuridae). Evol. Biol., 6, pp. 305-322.

C.C. Black, K. Kowalski, 1974. The Pliocene and pleistocene sciuridae (mammalia, rodentia) from Poland. Acta zool. Cracov., 19, pp. 461-486.

N.S. Bolikhovskaya, S.S. Faustov, A.K. Markova, 2015. Pleistocene climatic stratigraphy and environments of the Terek-Kuma Lowland (NW Caspian sea region) inferred from palynological, paleomagnetic and rodent records of the long Otkaznoye sediment sequence. Quat. Int., 30 (1), pp. 16-32. 
M.M. Bortniak, V.M. Liubchenko, Y.O. Voitiuk, T.V. Goliachenko, 1991. [Flora of mykhailivsky pine forest in Cherkassy area]. Herald of kiev national University. Chem. Biol. Ser. Earth Sci., 1, pp. 44-50 (in Ukrainian).

O.V. Brandler, I.Y. Biryuk, O.A. Ermakov, S.V. Titov, V.L. Surin, V.P. Korablev, V.A. Tokarsky, 2015. [Interspecies and intraspecific molecular genetic variability and differentiation in speckled ground squirrels Spermophilus suslicus and S. odessanus (Rodentia, Sciuridae, Marmotini)]. The Journal of V.N.Karazin Kharkiv National University Ser. Biol., 24 (1153), pp. 58-67 (in Ukrainian).

D.D. Chemagina, T.V. Strukova, N.V. Pogodina, 2016. Ground squirrel (rodentia, sciuridae) from the localities of middle trans-urals. The 100th anniversary of Russian Paleontological society. Problems and Prospects of Paleontological Researches: the Materials of the LXII Session of Paleontological Society, VSEGEI, St. Petersburg, pp. 278-279, 4-8 April, 2016.

N. Ćosić, Š. ̌̌íčanová, J. Bryja, A. Penezić, D. Ćirović, 2013. Do rivers and human-induced habitat fragmentation affect genetic diversity and population structure of the European ground squirrel at the edge of its Pannonian range? Conserv. Genet., 14 (2), pp. 345-354.

N.I. Dmitriev, 1938. Land forms of Ukraine created by glacier accumulation and erosion of the Dnieper Glacier. D.A. Petrovskiy, V.A. Yazykov (Eds.), Proceedings of the Second International Conference of INQUA. State Science-technical Mining-geological Edition, Leningrad, pp. 54-70.

O.A. Ermakov, S.V. Titov, 2000. Dynamics of the range boundary of russet ground squirrel from the Volga area. Zool. J. Linn. Soc., 79 (4), pp. 503-509.

O.A. Ermakov, V.L. Surin, S.V. Titov, N.A. Formozov, 2006a. Molecular genetic study of maternal and paternal lineages of hybridization of ground squirrels (Spermophilus: rodentia, Sciuridae). Bulletin of Moscow society of Naturalists. Biol. Ser., 111 (5), pp. 4-7 (in Russian)

O.A. Ermakov, S.V. Titov, A.B. Savinetsky, V.L. Surin, S.S. Zborovsky, E.A. Lyapunova, N.A. Formozov, 2006b. Molecular genetic and palaeoecological arguments for conspecificity of little (Spermophilus pygmaeus) and Caucasian Mountain (S. musicus) ground squirrels. Zool. J. Linn. Soc., 85, pp. 14741483.

O. Fejfar, W.-D. Heinrich, 1983. Arvicoliden-Sukzession und Biostratigraphie des Oberpliozäns und Quartärs in Europa. Schriftenr. für Geol. Wiss., 19 (20), pp. 61-109.

N.S. Filipchuk, O.I. Lashkova, O.M. Paliukh, 2005. Craniological characteristics characters of the allopatric rodent group Spermophilus suslicus. Proceedings of national dragomanov teachers' training university. Ser. Biol., 1 (1), pp. 70-80 (in Ukrainian).

C. Gamble, 2003. Timewalkers: the Prehistory of Human Global Colonisation. Sutton Publishing Ltd., Stroud (2003).

S.N. Gashev, E.A. Bykova, N.V. Sorokina, 2012. "Zelenye koridory» kak faktor podderzhaniya bioraznobraziya v urbanisirovannykh landshaftakh ["Green corridors" as factors to maintain biodiversity in urban landscapes]. Izv. Samar. nauchonnogo tsentra Rus. Akad. Nauk., 14, pp. 1-9, in Russian. 
M. Germonpré, M. Sablin, G.A. Khlopachev, G.V. Grigorieva, 2008. Possible evidence of mammoth hunting during the epigravettian at yudinovo, Russian plain. J. Anthropol. Archaeol., 27 (4), pp. 475492

P.L. Gibbard, K.M. Cohen, 2008. Global chronostratigraphical correlation table for the last 2.7 million years. Episodes, 31 (2), pp. 243-247

P.L. Gibbard, J. Lewin, 2002. Climate and related controls on interglacial fluvial sedimentation in lowland Britain. Sediment. Geol., 151 (3) (2002), pp. 187-210

G. Goretskiy, 1970. Alluvial Chronicle of the Great Ancient Dnieper. Nauka, Moscow.

I.M. Gromov, 1957. Materialy po istorii fauny gryzunov nizhnego urala i severnogo Prikaspiya [materials on the faunal history of rodents of the lower ural and northern Pricaspia]. Tr. Zool. Inst. Akad. Nauk. SSSR, 22, pp. 192-245.

I.M. Gromov, 1961. Fossil upper quaternary rodents of the submountain Crimea. Proceedings of Commission on the Study of the Quaternary Period, pp. 17-19.

I.M. Gromov, M.A. Erbaeva, 1995. Mammals of Russia and Adjacent Countries: Lagomorphs and Rodents. Zoological Institute of the Academy of Science of the USSR, St. Petersburg.

I.M. Gromov, D.I. Bibikov, N.I. Kalabukhov, M.N. Mejer, 1965. Fauna SSSR. Mlekopitayushchie. Tom III/2. Nazemnye Belichi (Marmotinae). Nauka, Moskva, Leningrad.

E. Güleç, F.C. Howell, T.D. White, 1999. Dursunlu - a new lower Pleistocene faunal and artifactbearing locality in southern Anatolia. H. Ullrich (Ed.), Hominid Evolution: Lifestyle and Survival Strategies, Edition Archea, Berlin, pp. 349-364.

I. Gündüz, M. Jaarola, C. Tez, C. Yeniyurt, P.D. Polly, J.B. Searle, 2007. Multigenic and morphometric differentiation of ground squirrels (Spermophilus, Scuiridae, Rodentia) in Turkey, with a description of a new species. Mol. Phylogenet. Evol., 43 (3), pp. 916-935.

H. Gür, 2013. The effects of the Late Quaternary glacial-interglacial cycles on Anatolian ground squirrels: range expansion during the glacial periods? Biol. J. Linn. Soc., 109 (1), pp. 19-32

M.K. Gür, H. Gür, 2010. Spermophilus xanthoprymnus (rodentia: sciuridae)

Mamm. Species, 42, pp. 183-194.

F.K. Hare, 1983. Climate and desertification: a revised analysis. World Climate Applications Programme, World Meteorological Organization, Geneva.

R.G. Harrison, S.M. Bogdanowicz, R.S. Hoffmann, E. Yensen, P.W. Sherman, 2003. Phylogeny and evolutionary history of the ground squirrels (rodentia: marmotinae). J. Mamm. Evol., 10 (3), pp. 249276

W.-D. Heinrich, 1978. Biometrische Untersuchungen an fossilen Kleinsäugetieren aus einer jungpleistozänen Deckschichtenfolge über dem interglazialen Travertin von Burgtonna in Thüringen. Quartärpaläontologie, 3, pp. 255-268 
K.M. Helgen, R.F. Cole, L.E. Helgen, D.E. Wilson, 2009. Generic revision in the holarctic ground squirrel genus Spermophilus. J. Mammal., 90 (2), pp. 270-305

G.E. Hutchinson, 1959. Homage to Santa-Rosalia, or why are there so many kinds of animals? Am. Nat., 93 (870), pp. 145-159

D. Jánossy, 1962. Vorläufige Mitteilung über die Mittelpleistozäne Vertebratenfauna der TarkőFelsnische (NO-Ungarn, Bükk-Gebirge). Ann. Hist.-Nat. Musei Natl. Hung. pars Mineral. Palaeontol., 54, pp. $155-176$

D. Jánossy, 1975. Mid-Pleistocene microfaunas of continental Europe and adjoining areas. K.W. Butzer, G.L. Isaac (Eds.), After the Australopithecines. Stratigraphy, Ecology, and Culture Change in the Middle Pleistocene, Mouton Publishers, The Hague, Paris, pp. 375-397.

D. Jánossy, 1976. Die Felsnische Tarkő und die Vertebratenfauna ihrer Ausfüllung. Karszt- és Barlangkutatás, 8, pp. 3-106.

D. Jánossy, 1986. Pleistocene Vertebrate Faunas of Hungary. Elsevier Amsterdam (1986)

N.I. Kalabukhov, 1978. Zhizn' Zoologa (Polveka Izucheniya Mlekopitayushchikh I Drugikh Zhivotnykh [Life of a Zoologist (Half century of Study of Mammals and Other Animals)]. Izdatel'stvo Moskovskogo Universiteta, Moscow.

N.I. Kalabukhov, V.V. Raevskij, 1935. Izuchenie peredvizhenij suslikov v stepnoj rajonakh Servernogo Kavkaza metodom kol'ztsevniya [Study of migration of susliks in steppe territories of the Northern Caucasus with banding method]. Vopr. Ekol. i biogeotsenologii, 2, pp. 170-195.

G.A. Khlopachev, 2014. Absolute and relative age of the site Bugorok: geological, environmental and archaeological data. D. Stupak, G.A. Khlopachev (Eds.), Epigravettian Sites of Middle Dnipro Region, pp. 81-98 (in Russian).

T. Kormos, 1916. Die Felsnische Pilisszanto. Beiträge zur Geologie, Archäologie und Fauna der Postglazialzeit. Mittl. aus dem Jahrb. königlich Ung. Geol. Reichsanst., 23, pp. 331-523 Taf. 312-327.

K. Kowalski, 2001. Pleistocene rodents of Europe. Folia Quat., 72, pp. 1-389.

M. Krajcarz, M.T. Krajcarz, A. Nadachowski, O. Sytnyk, 2012. Remains of small mammals from fossil burrows in the archaeological Pleistocene site Ihrovytsya (western Ukraine). Acta Zool. Cracov., Ser. A Vertebr., 55 (1), pp. 89-96.

A.I. Krokhmal, L.I. Rekovets, 2010. Mestonakhozhdeniya Melkikh Mlekopitayushchikh Plejstotsena Ukrainy I Sopredel'nykh Territorij [Fossil Sites of Micromammals of the Pleistocene of Ukraine and Adjoining Territories]. LAT \& K, Kiev.

B. Kryštufek, V. Vohralík, 2005. Mammals of Turkey and Cyprus. Rodentia I: Sciuridae, Dipodidae, Gliridae, Arvicolinae. Science and Research Centre of the Republic of Slovenia, Koper.

B. Kryštufek, J. Bryja, E.V. Bužan, 2009. Mitochondrial phylogeography of the European ground squirrel, Spermophilus citellus, yields evidence on refugia for steppic taxa in the southern Balkans. Heredity, 103 (2), pp. 129-135. 
S. Kuhn, M.C. Stiner, 2010. Culture and Biology in transition : summary of findings and conclusion

F.C. Howell (Ed.), Culture and Biology at a Crossroads: the Middle Pleistocene Record of Yarımburgaz Cave (Thrace, Turkey), Ege Yayınları, Istanbul, pp. 301-319

A.A. Kuzmin, A.A. Shmyrov, S.V. Titov, 2011. Bol'shoj suslik (Spermophilus major Pall.) na Pravobereszh'e volgi: sovremennoe sostoyanie i rasprostranenie [The russet ground squirrel (Spermophilus major Pall.) on the Right bank of Volga: extant condition and distribution]. Proceedings of Penza State Pedagogical University, vol 25, pp. 210-215 (in Russian).

Y.A. Lavrushyn, Y.G. Chugunnyi, 1982. Kanev Glacial Dislocations. Nauka, Moscow (1982)

A.S. Lemesh, N.V. Pogodina, 2010. Modern northern border of the large ground squirrel Spermophilus major Pall. (Rodentia, Sciuridae) in the Trans-Urals (Sverdlovsk region). Biological Systems: Stability, Principles and Mechanisms of Functioning: the Materials of the III All-Russia. Scientific and Practical Conf. Nizhny Tagil, 1-5 March, 2010. Nizhny Tagil, pp. 368-371 (in Russian).

E.A. Lyapunova, 2007. [Phylogeny of holarctic ground-squirrels. Molecular-genetic study]. Bulletin of the moscow society of naturalists. Biol. Ser., 112 (1), pp. 3-12 (in Russian, with English summary).

A.K. Markova, 2007. Pleistocene mammal faunas of eastern Europe. Quat. Int., 160 (1), pp. 100-111.

A.K. Markova, 2011. Small mammals from Palaeolithic sites of the Crimea. Quat. Int., 231 (1-2), pp. 22-27.

A. Matoshko, P. Gozhik, A. Ivchenko, 2002. The fluvial archive of the Middle and Lower Dnieper (a review). Neth. J. Geosci. - Geol. En Mijnbouwkd., 81 (3-4), pp. 339-355.

Z.M. Matviishyna, N.P. Gerasimenko, V.I. Perederiy, A.S. Ivchenko, A.M. Bragin, 2010. Spatial and Temporal Correlation of Palaeogeographical Conditions of the Quaternary Period of Ukraine Area. Naukova dumka, Kyiv (in Ukrainian).

E. Mayr, 1963. Animal Species and Evolution. Harvard University Press, Cambridge, MA.

E. Meriç, 1995. Evidence of inter-connection between the Sea of Marmara and Black Sea via izmit bay-lake, sapanca and the sakarya valley prior to the Bosporus. Geosound (Çukurova Univ., Adana, Turkey), vol 27, pp. 149-158.

S. Montuire, S. Sen, J. Michaux, 1994. The Middle Pleistocene mammalian fauna from Emirkaya-2, Central Anatolia (Turkey): systematics and paleoenvironment. Neues Jahrbuch für Geologie und Paläontologie Abhandlungen, 193 (1), pp. 107-144.

A. Nadachowski, 1989. Origin and history of the present rodent fauna of Poland based on fossil evidence. Acta Theriol., 34 (1), pp. 37-53.

D. Nuzhnyi, P.S. Shydlovskyi, 2015. Variabilité de l'industrie lithique entre les structures de I'habitation no 1 de Mezhyrich, site du Paléolithique supérieur d'Ukraine. L'Anthropologie, 119 (4), pp. 394-416. 
S.O. Ozkurt, M. Sozen, N. Yigit, I. Kandemir, R. Colak, M. Gharkheloo, E. Colak, 2007. Taxonomic status of the genus Spermophilus (Mammalia: rodentia) in Turkey and Iran with a description of a new species. Zootaxa, 1529, pp. 1-15.

T. Park, 1954. Experimental studies of interspecies competition. II. Temperature, humidity and competition in two species of Tribolium. Physiol. Zool., 27, pp. 177-238.

V.G. Pazynych, 2004. Dnieper-river basin in the periglacial. P.1/Exchanging of the river discharge. Suputnyk of the Kyiv Geographic Almanac (second ed.) Kyiv (in Ukrainian).

S. Péan, S. Prat, 2014. Hommes et environnements au Paléolithique supérieur en Ukraine continentale et en Crimée: introduction. L'Anthropologie, 118 (5), pp. 479-482.

S. Péan, D. Nuzhnyi, S. Prat, 2015. Hommes et environnements au Paléolithique supérieur en Ukraine: introduction aux recherches interdisciplinaires menées sur le site de Mezhyrich. L'Anthropologie, 119 (4), pp. 349-354.

A. Petculescu, 2013. Paleoclimatic Reconstructions Based on Small Mammals from Carst Deposits Editura AGIR, Bucharest.

I.G. Pidoplichko, 1954. About the glacial period. A.P. Markevich (Ed.), Biological and Geographical Features of the European Representatives of the Quaternary Fauna, III, USSR Academy of Science, Kiev, pp. 1-220 (in Russian).

L.V. Popova, 2004. The micromammal fauna of the Dnieper Modern channel alluvium: taphonomic and biostratigraphic implications. Quaternaire, 15, pp. 233-242

L.V. Popova, 2013. Occlusive morphology as evidence of environmental conditions: lower pleistocene Spermophilus severskensis (Sciuriadae, Rodentia), Northern Ukraine. Palaeolandscapes from Saalian to Weichselian, South Eastern Lithuania: Abstracts: International Field Symposium, pp. 80-81.

L.V. Popova, 2015. Small mammal fauna as an evidence of environmental dynamics in the Holocene of Ukrainian area. Quat. Int., 357, pp. 82-92.

L.V. Popova, 2016a. Evolutionary lineage of Spermophilus superciliosus - S. fulvus (Rodentia, Sciuridae) in the quaternary of the Dnieper area: an ability of a biostratigraphical implication. Quat. Int., 420, pp. 319-328.

L.V. Popova, 2016b. Occlusal pattern of cheek teeth in extant Spermophilus: a new approach to the identification of species. J. Morphol., 277, pp. 814-825.

V.N. Povodyrenko, L.I. Rekovets, 2003. Comparative characteristic of mammal fauna of the Medzhibozh locality. P.F. Gozhik (Ed.), Theoretical and Applied Aspects of Recent Phanerozoic Biostratigraphy of the Ukraine, Kiev, pp. 168-170.

Z. Qiu, 1991. The neogene mammalian faunas of ertemte and harr obo in inner Mongolia (nei mongol), China. 8. Sciuridae (rodentia). Senckenberg. Lethaea, 71 (3/4), pp. 223-255. 
N. Ramos-Lara, J.L. Koprowski, B. Kryštufek, I.E. Hoffmann, 2014. Spermophilus citellus (rodentia: sciuridae). Mamm. Species, 46 (913), pp. 71-87.

L.I. Rekovets, 1979. Systematic position of ground squirrels from the Upper Pleistocene deposits of Ukraine. Zool. Her., 1 (1979), pp. 35-41 (in Russian).

L.I. Rekovets, 1985. Small Mammal Fauna of the Late Paleolithic of Desna-dnieper Area. Naukova dumka Press, Kiev.

L.I. Rekovets, 1994. Melkie Mlekopitayushchie Antropogena Yuga Vostochnoj Evropy (Small Mammals of the Anthropogene of Eastern Europe). Naukova dumka, Kiev.

L. Rekovets, A. Chepalyga, V. Povodyrenko, 2007. Geology and mammalian fauna of the middle pleistocene site, medzhybozh, Ukraine. Quat. Int., 160 (1), pp. 70-80.

L.I. Rekovets, S. Čermák, O. Kovalchuk, V. Prisyazhniuk, D. Nowakowski, 2014. Vertebrates from the middle pleistocene locality Lysa Gora 1 in Ukraine. Quat. Int., 326, pp. 481-491.

P.S. Repchenko, 1985. Khortitsya - Ukrains'ka Radyans'ka Entsiklopediya V. 12 Tomakh. Gol. redaktsiya URE, pp. 1974-1985. [Khoritsya - Ukrainian Home encyclopedia in 12 volumes].

J.W.F. Reumer, L.W.v.d Hoek Ostende, 2003. Petauristidae and sciuridae (mammalia, rodentia) from Tegelen, Zuurland, and the Maasvlakte (The Netherlands). Deinsea, 10, pp. 455-467.

J. Rodríguez, A. Mateos, C. Hertler, M.R. Palombo, 2016. Modelling human presence and environmental dynamics during the Mid-Pleistocene Revolution: new approaches and tools. Quat. Int., 393 (30), pp. 19-23.

W. Santel, W.v Koenigswald, 1998. Preliminary report on the middle Pleistocene small mammalian fauna from Yarimburgaz Cave in Turkish Thrace. Eiszeitalt. Ggw., 48, pp. 162-169

A.A. Shmyrov, 2006. Reproductive relationships of russet (Spermophilus major Pall.) and yellow (S. fulvus Licht.) ground squirrels in hybrid colony. Bulletin of Moscow society of Naturalists. Biol. Ser., 111 (5) (2006), pp. 4-17 (in Russian).

E.F. Shnyukov, V.M. Alenkin, D.E. Makarenko, 1981. Geology of Shelves of USSR: Kerch Strait. Naukova Dumka, Kiev.

P.S. Shydlovskyi, 2005a. The influence of physical environment on the formation of material culture of the Upper Palaeolithic Middle Dnieper area hunter societies. Problems of the Archaeology of Middle Dnieper Region, FDKM, Kyiv-Fastiv, pp. 31-39 (in Ukrainian).

P.S. Shydlovskyi, 2005b. "Mammoth migrations" and seasonal adaptation of population of middle dnieper area in upper Palaeolithic. Z.e. al (Ed.), Kamyana Doba Ukrainy, vol. 7, Shliah, Kyiv, pp. 73-77 (in Ukrainian).

P.S. Shydlovskyi, S.D. Lysenko, O.S. Kyrylenko, A.A. Sorokun, E.V. Pichkur, 2016. Primeval Archaeology of the Lower Desna Area, Kyiv 
V.V. Sivkov, 1962. Some ecological and physiological peculiarities of small and spotted ground squirrels at the border of the species ranfe in Kharkov region. Issues in Ecology of Land Vertebrates: Materials of IV Ecological Conference, vol. 6, Vyshchaya shkola Press, Moscow, pp. 137-138 (in Russian).

D.N. Sobolev, 2016. Nature of kanev dislocations. Bulletin of moscow society of naturalists. Geol. Ser., 4 (3-4), pp. 4-17 (in Russian).

O.I. Stadnyk, L.P. Dema, 2007. The ground squirrels (Spermophilus, rodentia) of the late Pliocene of Ukraine. P.F. Gozhik (Ed.), Paleontological Studies in Ukraine: History, Present-day State and Prospects: Collection of Scientific Work of IGS NAS of Ukraine, Kyiv, pp. 361-364.

\section{State Geological Map of Ukraine, 2004}

State Geological Map of Ukraine, 2004. Scale 1:200 000 Middle Ukrainian Series. Sheet M-36-XXVII. (Znamianka) - Explanatory Notes. State Committee of natural resources, Kyiv.

J.R. Stewart, C.B. Stringer, 2012. Human evolution out of Africa: the role of refugia and climate change. Science, 335 (2012), pp. 1317-1321

G. Storch, 1975. Eine mittelpleistozäne Nagerfauna von der Insel Chios, Ägäis (Mammalia: rodentia) Senckenberg. Biol., 56 (4/6), pp. 165-189.

G. Storch, 1988. Eine jungpleistozäne/altholozäne Kleinsäuger-Abfolge von Antalya, SW-Anatolien (Mammalia, Rodentia). Z. für Säugetierkd., 53 (2), pp. 76-82.

G. Storch, 2004. Late Pleistocene rodent dispersal in the Balkans.

H.I. Griffiths, B. Kryštufek, J.M. Reed (Eds.), 2004. Balkan Biodiversity - Pattern and Process in the European Hotspot, Kluwer Academic Publishers, p. 135-145.

A.J. Stuart, L.D. Sulerzhitsky, L.A. Orlova, Y.V. Kuzmin, A.M. Lister, 2002. The latest woolly mammoths (Mammuthus primigenius Blumenbach) in Europe and Asia: a review of the current evidence. Quat. Sci. Rev., 21, pp. 1559-1569.

A. Tchapalyga, 1995. Black Sea Plio-pleistocene basins and their interactions with the mediterranean

E. Meriç (Ed.), Quaternary Sequence of the Gulf of Izmst, Istanbul Univ, pp. 303-311.

A.S. Tesakov, 2004. Biostratigrafiya Srednego Pliotsena - Eoplejstotsena Vostochnoj Evropy (Po Melkim Mlekopitayushchim)[Biostratigraphy of Middle Pliocene - Eopleistocene of Eastern Europe (Based on Small Mammals)]. Nauka, Moskva.

S.V. Titov, A.A. Shmyrov, A.A. Kuzmin, 2012. Biotope principles of sympatry and interspecies hybridization in mammals (by the example of the genus Spermophilus). Biol. Bull., 39 (1), pp. 36-44.

V.A. Topachevskij, 1961. Історії фауни ссав “ів Середнього Придніпров'я Novi materiali do antropogenovoi istorii fauni ssavtsiv Seredn'ogo Pridniprov'ya [New materials for the Anthropogene 
history of the mammalian fauna of the Northern Dneper area]. 36 Prats' Zool. Muz. URSR, 30, pp. 920 (in Ukrainian).

M.V. Tsvirka, V.P. Korablev, 201. A case study of chromosomal speciation in little ground squirrel (Spermophilus pygmaeus) and Caucasian mountain ground squirrel (Spermophilus musicus, Rodentia, Sciuridae). Zool. J., 93 (7), pp. 917-925

K. Tsytsulina, I. Zagorodnyuk, N. Formozov, B. Sheftel, 2008. Spermophilus pygmaeus. The IUCN Red List of Threatened Species 2008: e.T14326A4431978.

https://doi.org/10.2305/IUCN.UK.2008.RLTS.T14326A4431978.enDownloaded on 15 June 2017.

V.V. Ukraintseva, 1985. Forage of the large herbivorous mammals of the epoch of the mammoth. Acta Zool. Fenn., 190, pp. 215-220

M.F. Veklich, 1977. Map of the Quaternary Deposites of Ukrainian and Moldavian SSR Trust Kievgeology, Kiev.

M.F. Veklich, 1989. Stages of the Black Sea and the Azov Sea development during the quaternary and their correlation with continental environments. Quaternary Period, Palaeogeography and Litology, Shtiintsa, Kishinev, pp. 102-118 (in Russian).

N.N. Vorontsov, E.A. Lyapunova, 1969. The Chromosomes of the palaearctic sousliks (Citellus, Marmotinae, Sciuridae, Rodentia). N.N. Vorontsov (Ed.), The Mammals (Evolution, Karyology, Fauna, Systematics). Proceeding from the Second All-Union Conference of Mammalogists, Moscow 23-27 December 1969], Academy of Sciences of the USSR, Siberian branch, Novosibirsk, pp. 41-47 (in Russian).

N.N. Vorontsov, E.A. Lyapunova, 1976. Genetics and problems of Trans-Beringian connections of Holarctic mammals. V.L. Kontrimavichus (Ed.), Beringia in the Cenozoic Era, Far-Eastern Scientific Centre Vladivostok, pp. 337-353.

V. Yanko-Hombach, S. Kroonenberg, S. Leroy, 2010. Caspian-Black Sea-Mediterranean corridors during the last 30 ka: sea Level change and human adaptive strategies. Quat. Int., 225 (2), pp. 147149.

D.I. Yavornitskij, 1990. Istoriya Zaporozhskikh Kozakov [History of the Zaporozh Kozaks]. Naukova dumka, Kiev.

I.V. Zagorodnyuk, 2002. Transitive taxonomic systems and their structure in ground squirrels (Spermophilus). Reports of National Academy of Science of Ukraine. Biol. Ser., 9, pp. 185-191

I.V. Zagorodnyuk, 2011. Interspecies hybridisation and factors of its formation in the EasternEuropean mammalian fauna. Stud. Biol., 52 (2), pp. 173-210 (in Ukrainian).

I.V. Zagorodnyuk, O.O. Fedorchenko, 1995. Allopatric species in the rodent group Spermophilus suslicus (Mammalia). Zool. Her., 56, pp. 49-58 (in Russian). 
I. Zagorodnyuk, Z. Glowacinski, A. Gondek, 2008. Spermophilus suslicus. The IUCN Red List of Threatened Species 2008: e.T20492A9208074.

https://doi.org/10.2305/IUCN.UK.2008.RLTS.T20492A9208074.en Downloaded on 16 June 2017.

V.A. Zubakov, 1986. Global Climatical Events of the Pleistocene. Gidrometeoizdat Press, Leningrad.

Š. Říčanová, Y. Koshev, O. Říčan, N. Ćosić, D. Ćirović, F. Sedláček, J. Bryja, 2013. Multilocus

phylogeography of the European ground squirrel: cryptic interglacial refugia of continental climate in Europe. Mol. Ecol., 22 (16), pp. 4256-4269. 